Is the risk of product market predation a cost of disclosure?

\title{
Darren Bernard
}

\author{
A dissertation \\ submitted in partial fulfillment of the \\ requirements for the degree of \\ Doctor of Philosophy
}

University of Washington

2016

Reading Committee:

David C. Burgstahler, Chair

Jonathan M. Karpoff

Dawn A. Matsumoto

Program Authorized to Offer Degree:

Business - Foster School of 
CCopyright 2016

Darren Bernard 


\title{
University of Washington
}

\begin{abstract}
Is the risk of product market predation a cost of disclosure?
\end{abstract}

Darren Bernard

Chair of the Supervisory Committee:

David C. Burgstahler, Julius A. Roller Professor of Accounting Business - Foster School of

Competitors engage in product market predation when they lower prices or increase expenditures on non-price competition with the goal of forcing a rival to exit. This study provides evidence consistent with the hypothesis that financially constrained firms avoid financial statement disclosure to mitigate the risk of product market predation. The empirical analysis examines German private firms, the majority of which failed to comply with financial statement public disclosure requirements until a regulatory change in 2006 dramatically increased the cost of noncompliance. The evidence suggests the relation between financial constraint and disclosure avoidance is increasing at an increasing rate. Consistent with the risk of predation driving this relation, the results are substantially stronger for firms with other characteristics linked to predation risk. Additional and supplemental tests, including a falsification test and analyses of ex post performance, reinforce my interpretation of the results. The findings suggest an important link between disclosure and financing decisions and contribute to the broader literature on proprietary costs of disclosure. 


\section{1: Introduction}

Competitors engage in product market predation (hereafter, "predation") when they lower prices or increase expenditures on non-price competition with the goal of forcing a rival to exit. The prior literature on predation is vast and considers both the motivations for predators and the determinants of predation risk for prey. This literature concludes that firms engage in predation for a number of reasons - e.g., to keep or attain high levels of market power, acquire competitors at lower cost, or deter current or future product market entrants - but do so only under certain conditions. For example, models of predation rely on important assumptions about the observability of firm contracts and financial characteristics; these papers show that the extent of information asymmetry between potential prey and external parties, such as capital providers, can be a determinant of predation risk (e.g., Bolton and Scharfstein, 1990). The literature also shows that targets of predation tend to be financially constrained, in the sense that they lack financial resources to survive even short price wars or other business downturns (e.g., Scott Morton, 1997).

In this paper, I examine evidence that financially constrained firms - that is, firms most vulnerable to predation - make disclosure decisions to preserve information asymmetries with potential predators. Financially constrained firms have incentives to avoid public disclosure of information that would help to resolve competitors' uncertainty about the costs and benefits of predation. For example, without the financial disclosures of rivals, potential predators are less clear about the financial resources, production capacity, and time needed for predation to be successful. Thus, just as some firms have incentives to withhold disclosure to avoid other proprietary costs, such as the threat of attracting a product market copycat into a highly 
profitable market (e.g., Botosan and Stanford, 2005), some firms have incentives to avoid revealing information about performance or financial position to mitigate predation risk. ${ }^{1}$

I test the effect of predation risk on disclosure decisions using data from German private firms following a 2006 regulatory change. Like most other European countries, Germany has had a requirement since the 1980s for all limited liability private firms to make certain annual financial statement information publicly available. ${ }^{2}$ However, unlike in most other European countries, in Germany this requirement was essentially unenforced for decades, and a majority of firms did not comply. In 2006, under pressure from the European Commission, the German government finally implemented a strict enforcement regime, which caused the rate of compliance to rise dramatically and financial statement information to become available for firms that had previously avoided disclosure (Henselmann and Kaya, 2009). I test whether the level of financial constraint helps to explain the choice to avoid financial statement disclosure until this enforcement change.

This setting has several advantages for examining the effect of predation risk on disclosure decisions. First, Germany requires all limited liability private firms to prepare full accounts for shareholders regardless of public disclosure decisions (Kaya, 2010), so it is implausible that firms in this setting avoid public disclosure due to incremental costs of financial

\footnotetext{
${ }^{1}$ Prior court cases provide anecdotal evidence that predators rely on information about the prey's financial resources. Bolton et al. (2000) summarize evidence from a case of alleged predation by the monopoly cable provider in Sacramento, California: "[T] he incumbent was attempting to raise entrant's cost of capital so as to exclude entrant as a rival and deter further entry. The whole purpose of the incumbent's price cutting strategy was to raise the entrant's cost of capital and discourage future contributions from its investors. Indeed, an internal memorandum from the incumbent's files assesses the entrant's financial resources, focusing on the net worth of its two principals, comparing this with the resources of a previous entrant who had also abandoned the market after severe price cutting by incumbent. More striking still, another memorandum from incumbent's files speaks of sending a message to entrant's bankers."

${ }^{2}$ The Appendix describes the financial information that German limited liability private firms are required to publicly disclose.
} 
statement preparation or agency costs (Vashishtha, 2014; Berger, 2011). ${ }^{3}$ Second, information about financial constraint contained in the financial statements of German private firms is not typically available to rivals except through public disclosure. For example, there are virtually no outside sources of information that reveal a private firm's financing characteristics, which is information critical to evaluating a rival's financial constraint and, therefore, vulnerability to predation. Third, financial statement filings of German private firms are generally reliable, as these filings form the basis of tax returns in Germany, ${ }^{4}$ so publicly disclosed financial statement information is effectively under the scrutiny of tax authorities (Hanlon et al., 2014). ${ }^{5}$

I hypothesize that the probability of disclosure avoidance prior to the enforcement change is increasing in financial constraint at an increasing rate. This hypothesis stems from theory and prior evidence that predation risk is non-linear in financial constraint - that is, particularly concentrated at the highest levels of financial constraint (Campello, 2006; Opler and Titman, 1994). I measure financial constraint using industry-adjusted book leverage net of cash based on evidence that financial constraint is increasing in observable leverage ratios and decreasing in cash holdings (e.g., Kaplan and Zingales, 1997). By adjusting the book leverage of the firm (net of cash) by the industry average, I isolate within-industry (i.e., relative to rivals) differences in financial constraint (e.g., Campello, 2006). ${ }^{6}$ The results show that financial constraint has a

\footnotetext{
${ }^{3}$ Prior to 2006, private disclosure requirements to shareholders were subject to substantially stronger enforcement than public disclosure requirements. Shareholders possessed well-enforced information rights regarding important planning decisions (e.g., investment decisions) and specific documents (e.g., contracts) in addition to the firm's financial statements. See, for example: Oberlandesgericht Thüringen, September 14, 2004 (Case 6 W 417/04).

${ }^{4}$ Prior work underscores the high level of book-tax conformity for German private firms (Szczesny and Valentinčič, 2013; Watrin et al., 2012; Kaya, 2010; Eierle et al., 2007; Eberhartinger, 1999). For example, Eierle et al. (2007) survey small and medium-sized firms in Germany and find that roughly $80 \%$ of companies prepare only one set of accounts for tax and financial purposes.

${ }^{5}$ Further, firms above certain size thresholds are required to be audited every year (see Appendix). As discussed below, I impose a selection criterion related to one of these size thresholds such that firms in my sample are likely to be audited.

${ }^{6}$ Alternative proxies for financial constraint include the KZ Index (Lamont et al., 2001) and the WW Index (Whited and $\mathrm{Wu}, 2006$ ). I cannot use these measures because certain data necessary for constructing them are unavailable for
} 
strong positive relation with disclosure avoidance, and this relation is greater at higher levels of financial constraint. Further, estimated marginal effects show that the relation between financial constraint and disclosure avoidance is economically significant compared to other determinants of disclosure avoidance studied in prior literature, such as profitability (e.g., Dedman and Lennox, 2009).

I also conduct a number of cross-sectional tests based on prior literature that suggests predation risk is a function of firm and industry characteristics in addition to financial constraint. For example, prior literature shows that easier access to external financing (for the preying firm) can facilitate predation (e.g., Bolton et al., 2000), so predation risk is likely to be higher in industries with a public rival. Prior literature also suggests that predation risk is generally greater for firms that do not rely on "ex ante" sales contracts and for firms smaller or less profitable than rivals (Scott Morton, 1997; Chevalier, 1995; Weiman and Levin, 1994; Burns, 1986). The results of the cross-sectional tests provide evidence consistent with these predictions. Overall, the findings suggest that the strength of the link between financial constraint and disclosure avoidance depends on factors important to predation risk but less clearly related to potential alternative explanations, such as the notion that managers of financially constrained firms avoid public disclosure to other firm counterparties, like suppliers or customers.

Finally, I conduct a series of supplemental analyses to provide additional evidence on my interpretation of the findings. A falsification test in the spirit of Badertscher et al. (2013) suggests that the results do not extend to the UK, which did not implement an analogous enforcement change in 2006. Consistent with firms using disclosure decisions to mitigate competitive threats, I also find evidence that more financially constrained German private firms 
delayed public disclosure during the implementation of the new enforcement regime. Further, in ex post analyses, I find that the relation between subsequent firm performance (e.g., changes in market share) and financial constraint is generally more negative for firms that previously avoided disclosure relative to German firms that did not avoid disclosure or otherwise similar UK firms. These results are consistent with the enforcement change facilitating predatory behavior and provide evidence on the real effects of German private firms' disclosure decisions (e.g., Shroff et al., 2014).

The study contributes to two bodies of literature. First, the paper provides evidence of a proprietary cost of disclosure fundamentally different from those examined in prior studies. Whereas prior papers show that firms avoid disclosures that could attract copycats into product segments or reveal useful information about customers and material contracts (e.g., Ellis et al., 2012; Verrecchia and Weber, 2006; Botosan and Stanford, 2005), I present evidence that suggests financing characteristics constitute important proprietary information due to predation risk. The evidence also furthers our understanding of the relation between proprietary costs and profitability. Although prior work generally finds that more profitable firms incur higher proprietary costs of disclosure (e.g., Dedman and Lennox, 2009), my findings suggest that this association is weaker among firms with higher levels of financial constraint, consistent with the notion that less profitable, more financially constrained firms have higher predation risk.

Second, the paper adds to the literature on product market predation. Prior theory suggests information asymmetries between potential prey and external parties, including capital providers, can affect predation risk (e.g., Bolton and Scharfstein, 1990). I provide evidence that private firms can withhold financial disclosures to raise rivals' uncertainty about the costs and benefits of predation. These results complement existing findings in the predation literature, 
which suggest that firms also make financing and hedging decisions to mitigate predation risk (Haushalter et al., 2007).

\section{2: Mandatory disclosure regime in Germany}

Under German law, limited liability private firms have been required to publicly disclose certain annual financial statement information since 1987, consistent with European Commission Directives on firm disclosure (namely, the 1968 and 2003 EU Corporate Disclosure Directives). When these requirements were adopted, the responsibility to monitor compliance was delegated to local courts. However, the local courts in Germany failed to enforce an effective system of monetary penalties to punish non-compliance, which led the majority of firms to choose to not comply with the public disclosure requirements (e.g., Henselmann and Kaya, 2009). ${ }^{7}$

Events in the late-1990s and mid-2000s pressured the German government to address the systematic non-compliance with public disclosure requirements. In a court case decided in December 1997 (CASE C-97/96), the European Court of Justice ruled that the German government had failed to implement an effective system of sanctions to ensure compliance with EU public disclosure requirements. A statement by the European Commission in September 1998 (CASE C-191/95) similarly concluded that the German government had failed to meet its obligations under EU Directives. In 2003, the European Commission issued a directive mandating that all European firms make their annual financial statements available as electronic filings at a national register beginning January 1, 2007.

In April 2005, a ministry of the German federal government introduced the draft bill "EHUG” (Electronic Commercial and Company Registrar, Gesetz über elektronische

\footnotetext{
${ }^{7}$ See Kaya (2010) for a summary of evidence from the German practitioner literature that proprietary costs of disclosure were an important reason firms avoided disclosure during this period.
} 
Handelsregister und Genossenschaftsregister sowie das Unternehmensregister), which proposed to create a central monitor of financial statement filings and impose substantial penalties on firms that fail to comply with public disclosure requirements. The "EHUG" bill was debated and revised for several months before the federal government formally endorsed it in December 2005. The bill was then debated and revised for eleven more months before it was enacted in November 2006. The new enforcement regime became effective for fiscal years ending December 31, 2006 and later. Figure 1 presents a timeline of the major events and law changes affecting German private firms' public disclosure requirements since 1987.

\section{$<$ FIGURE 1 $>$}

The passage of "EHUG" changed a de facto voluntary disclosure regime into a mandatory disclosure regime. Prior to the change in disclosure enforcement, the cost of withholding disclosure was relatively low due to the lack of effective enforcement. Therefore, financially constrained firms that anticipated some risk of predation could withhold financial statements that would have revealed important information about their vulnerability to predation. In contrast, after the change in enforcement, the substantial penalties made non-compliance prohibitively costly for most firms, which led firms that previously avoided disclosure to finally disclose. Thus, by comparing the previously unobservable characteristics of firms that did not disclose prior to the passage of "EHUG" against those that did disclose, I can test whether high levels of financial constraint are related to decisions to withhold financial disclosures. ${ }^{8}$

\footnotetext{
${ }^{8}$ It is possible that some firms took actions to reduce their vulnerability to predation before the implementation of "EHUG," particularly if firms anticipated the bill's passage when it was first introduced in April 2005 (or, more likely, when the federal government formally endorsed the bill in December 2005). As a result, the level of financial constraint I observe for some firms may be understated relative to their constraint prior to the implementation of the new enforcement regime.
} 


\section{3: Hypothesis development}

\section{1: Predation risk, financial constraint, and disclosure avoidance}

Competitors engage in predation when they lower prices or increase expenditures on nonprice competition with the goal of forcing a rival to exit. ${ }^{9}$ The word "exit" here does not necessarily mean bankruptcy or liquidation - exit can also take other forms such as exit from a specific product market or the sale of the firm to the predator (e.g., Burns, 1986). Additionally, my definition of predation does not limit the scope of predation to competition among established firms. For example, the analytical literature considers predation by established firms on potential entrants (e.g., Fudenberg and Tirole, 1986), and it is also possible that an entrant exploits an incumbent's financial constraint to rapidly establish itself in a new industry. ${ }^{10}$

The extant literature mainly focuses on firm characteristics and industry conditions that facilitate predation. For example, Chevalier (1995) finds evidence that firms that recently underwent leveraged buy-outs (LBOs) in the supermarket industry are often undercut on prices and forced to exit local markets if rivals are relatively unlevered. Bolton and Scharfstein (1990) argue that firms can become financially constrained and targeted for predation even in the absence of major leveraging events or industry or macroeconomic shocks (i.e., predation occurs even in equilibrium). They model the firm's optimal managerial contract and show that investors can mitigate incentive problems by providing funding in stages and committing to terminate

\footnotetext{
${ }^{9}$ This definition of predation follows Fudenberg and Tirole (1986), though prior papers (and court rulings) use a variety of other definitions that capture specific characteristics or mechanisms of predation (e.g., Haushalter et al., 2007; Scharfstein, 1984; Ordover and Willig, 1981). I make no prediction regarding how predation happens in my setting, so I follow an existing definition of predation that is generally inclusive of most other definitions.

${ }^{10}$ The case of Diapers.com provides an apparent example of predation. In 2005 Marc Lore founded Quidsi, the parent company for several consumer products businesses, including the website Diapers.com. Based largely on the success of its diaper business, Quidsi grew to about $\$ 300$ million in annual sales by 2010. "Then Amazon took notice of Quidsi's rise and, in the fall of that year, cut diaper prices by a third," Brad Stone writes in the January 12 January 18, 2015 issue of Bloomberg Businessweek (pg. 44). "Lore calculated at one point that Amazon was on track to lose $\$ 100$ million over three months on diapers alone. Quidsi's profitability sank, and Lore was forced to sell out to Amazon during the Great Recession, when additional capital to fund the fight was impossible to obtain."
} 
funding if firm performance is poor. The disadvantage is that the financial constraints imposed by the contract give rivals the incentive to prey and ensure the firm's performance is poor. One implication of their model is that firms and their capital providers are likely to contract to alleviate financing constraints when an external shock increases predation risk. Haushalter et al. (2007) provide empirical evidence consistent with this idea; in particular, they show that firms actively manage predation risk by building cash holdings and taking derivative positions to ensure key investments can be financed internally under the threat of predation. ${ }^{11}$

In addition to financing and hedging decisions, it is also plausible that managers make disclosure decisions partly to lower predation risk. Financial statement disclosures contain reliable information that can inform competitors about the likely costs and benefits of predation. For example, basic income statement and balance sheet disclosures contain information about a firm's size, leverage, liquidity, and operating performance, all of which are determinants of financial constraint and, therefore, the firm's vulnerability to predation (Hadlock and Pierce, 2010). By withholding financial disclosures, then, firms can raise a potential predator's uncertainty about the efficacy of a predatory product market strategy, including the financial resources, production capacity, and time needed for predation to be successful. In this way, disclosure avoidance can act as a wedge between rivals, whereby potential predators may lose the ability to reliably identify vulnerable prey.

Of course, the incentive to withhold disclosure depends on the critical assumption that the act of non-disclosure is not itself completely informative of the firm's type. In essence, this

\footnotetext{
${ }^{11}$ To the extent firms anticipate and manage predation risk, predators could be better off buying their prey rather than preying (see e.g., Bolton et al., 2000). However, not all prey are willing to sell, especially if the managers obtain some private benefits of control. Further, purchasing competitors can attract new entrants similarly hoping to be bought out. This reasoning is sometimes used to explain why, at the turn of the $20^{\text {th }}$ century, American Tobacco Company preyed on rivals to reduce their value before purchasing them (Burns, 1986).
} 
condition requires that some managers have incentives to avoid disclosure for reasons unrelated to the threat of predation; otherwise, the act of non-disclosure would be fully informative to competitors. Ex ante, this condition is likely to be satisfied, as prior literature suggests that firms withhold information for a number of reasons, such as to avoid drawing product market copycats into profitable product markets. ${ }^{12}$

Thus, I predict that financially constrained German private firms were likely to "stay dark" until penalties for non-disclosure began to be enforced in $2006 .{ }^{13}$ Specifically, the threat of predation suggests that financial constraint is positively related to disclosure avoidance, where the strength of the relation increases at higher levels of financial constraint. This prediction is based on theory and prior empirical evidence that the risk of predation is non-linear in financial constraint - that is, relatively low for firms with low to moderate levels of financial constraint but particularly pronounced for firms with high levels of financial constraint, which have met or exceeded their borrowing capacity and are most vulnerable to conflicts between managers and capital providers (Campello, 2006; Opler and Titman, 1994; Bolton and Scharfstein, 1990).

The first hypothesis, in alternative form:

H1a: Firms that are more financially constrained are more likely to avoid public disclosure of financial statement information.

H1b: The relation between financial constraint and disclosure avoidance is more positive at higher levels of financial constraint.

\footnotetext{
${ }^{12}$ For example, Dedman and Lennox (2009) examine the propensity for medium-sized UK private firms to withhold sales and cost of goods sold disclosure. They find that better performing firms - namely, firms with higher gross profit margins - are less likely to disclose. In contrast, the threat of predation would generally make less profitable firms more likely to avoid disclosure, particularly to the extent these firms face other financing constraints. Put differently, whereas most prior papers on proprietary costs examine the competitive incentives for firms to avoid revealing "strength," I examine an incentive for firms to avoid revealing "weakness."

${ }^{13}$ The benefits associated with voluntary financial statement disclosure are generally low in the private firm setting. However, prior literature shows that private firms often disclose more than required, and this voluntary disclosure is substantially more common among larger firms (Dedman and Lennox, 2009). Contracting incentives at least partly explain these findings. Although information can be disclosed to counterparties through private channels, which in principle avoids disclosure to competitors, firms whose size or business models lead them to contract with large numbers of counterparties may simply choose to publicly disclose information due to the sheer volume of "confidential" disclosures.
} 


\section{2: Cross-sectional evidence of predation risk on disclosure decisions}

I develop cross-sectional predictions of the interactive effect of several firm and industry characteristics on the relation between financial constraint and disclosure avoidance. Although these firm and industry characteristics are likely to affect predation risk, they generally have no clear relation to potential alternative explanations for the association between financial constraint and disclosure avoidance, as discussed further below.

\subsection{1: Relative size}

Size relative to rivals is an important characteristic that partially determines susceptibility to predation. Large firms typically have more diverse operations and more financial flexibility than small firms (e.g., Hadlock and Pierce, 2010), which means that predation on a large firm, whether by another large firm or by a number of small firms, is relatively costly and less likely to succeed. ${ }^{14}$ In contrast, small firms can be targeted by other small firms or by large firms. For example, prior literature shows that large firms prey on small rivals to acquire them more cheaply, undermine their growth, force price accommodation, capture additional market power, or deter current or future product market entrants (Bolton et al., 2000; Chevalier, 1995; Weiman and Levin, 1994; Burns, 1986; Milgrom and Roberts, 1982). These factors suggest that the risk of predation, and therefore the probability of disclosure avoidance, is concentrated among firms smaller than industry rivals. ${ }^{15}$

\footnotetext{
${ }^{14}$ Because production capacity and financing constraints would impede a small firm's ability to prey on a large rival, small firms would need to collude to drive a large competitor out of business. However, the mechanisms of collusion are difficult to create and maintain. See Porter (2005) for a review of the problems inherent in collusive arrangements.

${ }^{15}$ This prediction is consistent with the view of antitrust authorities, who often note that predation is a widespread concern among firms with larger, more dominant rivals. For instance, in a review of competition in the fuel sector in 2011, Germany's antitrust authority, the Federal Cartel Office (Bundeskartellamt), noted that the issue of predatory pricing "is a pressing one for small and medium-sized oil companies." See: http://www.bundeskartellamt.de/Shared Docs/Publikation/EN/Sector\%20Inquiries/Fuel\%20Sector\%20Inquiry\%20-\%20Final\%20Report.pdf?_blob= publicationFile\&v=14.
} 
The second hypothesis, in alternative form:

H2: The relation between financial constraint and disclosure avoidance is more positive for firms smaller than industry rivals.

\subsection{2: Relative operating profitability}

The risk of predation implies that the effect of profitability on disclosure choices is likely to depend on the firm's financial constraint. Firms with low or negative levels of profitability are more susceptible to predation, as these firms are less likely to generate cash flows sufficient to finance investments internally or meet existing debt service obligations. Likewise, firms that are merely less profitable than industry rivals are also more susceptible to predation, as these firms are plausibly higher cost producers in their industries. ${ }^{16}$ Thus, the positive relation between profitability and disclosure avoidance documented in prior literature is likely to be concentrated among firms facing little threat of predation (e.g., Dedman and Lennox, 2009). That is, while highly profitable firms are more likely to avoid disclosure than unprofitable firms, this effect is likely to be diminished or reversed among financially constrained firms, as unprofitable and financially constrained firms are particularly vulnerable to predation.

The third hypothesis, in alternative form:

H3: The relation between financial constraint and disclosure avoidance is more positive for firms less profitable than industry rivals.

\subsection{3: Public firm presence}

Public firm presence is likely to be associated with greater predation risk for two reasons.

First, a common finding in the literature on predation is that cheaper and easier access to

\footnotetext{
${ }^{16}$ Relative-to-rivals profitability is an important determinant of predation risk as lower cost producers can outlast higher cost producers during a price war. For example, a Moody's research report in late 2014 noted that a key assumption behind the aggressive supply push by major iron ore producers is that "high-cost producers will need to exit the market." See: https://www.moodys.com/research/Moodys-Increases-in-iron-ore-supply-creating-risk-formarket--PR_310815?WT.mc_id=AM WWFob29fRmluYW5jZTQyX1NCX1JhdGluZyBOZXdzX0FsbF9Fbmc\%3 D 20141017_PR_310815.
} 
financing is an important condition for preying on product market rivals (e.g., Bolton et al., 2000; Chevalier, 1995). As a result, private firms are likely to be more vulnerable to predation by public firms, which have on average lower debt levels (that is, are generally less financially constrained) than private firms and face lower absolute costs when accessing external capital markets (Brav, 2009).

Second, firms are sensitive to industry uncertainty, in the sense that a lack of information about rivals' financing and investment decisions makes the outcomes of their own decisions less certain (Dixit and Pindyck, 1994). As a result, the more opaque the information environment of an industry, the more firms hold back on potential investment opportunities. For the same reasons, the propensity to engage in predation is likely to be muted in the presence of industry uncertainty - a firm will not prey unless its managers are reasonably certain to recoup the costs of predation in a future period (Bolton et al., 2000). In this context, public firms can enrich the industry's information environment and thereby facilitate predation. Consistent with this, Badertscher et al. (2013) present analogous evidence that the availability of public firm disclosures reduces industry uncertainty and thereby improves the responsiveness of other firms' investment decisions to potential investment opportunities.

The fourth hypothesis, in alternative form:

H4: The relation between financial constraint and disclosure avoidance is more positive for firms in industries with public rivals.

\subsection{4: Ex ante sales contracting}

The characteristics of sales contracting constitute another important dimension of industry competition likely to affect the risk of predation. In particular, the use of "ex ante" sales contracts (i.e., sales contracts signed in advance of production and delivery) mitigate the risk of predation. These contracts reduce the net benefits of predation by giving prey more time to raise 
capital or take other actions to respond to predatory competition. For example, whereas a price war has an immediate financial and operational effect on a firm (such as a supermarket) that relies primarily on ad hoc sales, it has a more lagged effect on a firm (such as a supplier of parts to an airplane manufacturer) that has secured important sales contracts in advance.

Long-term supply contracts are a subset of "ex ante" sales contracts particularly likely to mitigate the risk of predation. The use of a long-term supply contract makes it costly for an outside party to steal a firm's business with a customer. A customer is unlikely to break its contract with the supplier unless the outside party offers substantially better prices or terms of trade, which would per se erode the benefit of preying on the existing supplier. Scott Morton (1997) makes a similar point about the role of supply contracts in mitigating predation risk facing product market entrants: "Contracts secured by an entrant before entry will make a... price war less effective in reducing an entrant's financial resources, and therefore longer, less likely to succeed, and less likely to be undertaken... [E]ntrants with contracts should not be preyed upon" (pg. 701).

The fifth and final hypothesis, in alternative form:

H5: The relation between financial constraint and disclosure avoidance is more positive for firms in industries where the use of "ex ante" sales contracting is less common.

\section{4: Empirical methodology}

I construct a model of disclosure avoidance prior to the enforcement change using data drawn from Amadeus, a Bureau van Dijk database widely used in studies of both public and private European firms (e.g., Burgstahler et al., 2006). All independent variables are measured as of the firm's fiscal year ending between December 31, 2006 and December 30, 2007 - the first annual period after the new enforcement regime went into effect and financial statement data became available for most firms. Thus, the values of industry and firm characteristics in the first 
year following the enforcement change are used as proxies for these characteristics in earlier years when managers chose whether to avoid financial statement disclosure. ${ }^{17}$

Equation (1) presents the primary model specification:

(1) No disclosure $=f\left(\begin{array}{c}\beta_{0}+\beta_{1} \times \text { Industry adjusted leverage net of cash } \\ +\beta_{2} \times \text { Industry adjusted leverage net of cash }{ }^{2}+\text { Controls }+\varepsilon\end{array}\right)$

I proxy for the firm's decision to not disclose prior to the enforcement change using an indicator variable that equals one if the firm first appears in the Amadeus database for its fiscal year-end between December 31, 2005 and December 30, 2006 or December 31, 2006 and December 30, 2007, and zero otherwise. ${ }^{18}$ Although the new enforcement regime did not take effect until fiscal years ending December 31, 2006 or later, the number of observations on Amadeus increases substantially from calendar year 2004 to calendar year 2005, and again from calendar year 2005 to 2006 (see Table 3 Panel B in Bernard et al., 2015). Since private firms have up to 12 months after the end of the fiscal year to file annual accounts under the German Commercial Code (Section 325), most firms were still within the filing deadline for their 2005 accounts when "EHUG" was passed in November 2006 (e.g., Bauer and Bigus, 2014). Thus, the increase in filing compliance between 2004 and 2005 suggests that many firms filed 2005 accounts once it became apparent that disclosure requirements would finally be enforced. As a result, firms that first filed either 2005 or 2006 accounts are classified as disclosure avoiders. ${ }^{19}$

One possible concern given the research design is that there may have been a change in data coverage on Amadeus for German private firms roughly concurrent with the enforcement

\footnotetext{
${ }^{17}$ Most variables studied in prior papers on disclosure avoidance (e.g., firm size, industry structure) are highly persistent. For example, book leverage is highly persistent for public firms and even more so for private firms (Brav, 2009; Lemmon et al., 2008), so the firm's leverage in 2006 or 2007 is likely to closely approximate the firm's leverage during earlier periods.

${ }^{18}$ Data are generally unavailable on Amadeus for years prior to 2000, so to not be classified as a disclosure avoider, the firm must have filed financials for any fiscal year ending between January 1, 2000 and December 30, 2005.

${ }^{19}$ The main results are robust to an alternative specification for which only firms that delayed filing until fiscal years ending between December 31, 2006 and December 30, 2007 are classified as disclosure avoiders.
} 
change. If a change in data coverage is systematically associated with certain firm characteristics (such as poor performance), the tests could mistakenly conflate disclosure avoidance with a lack of database coverage. However, articles in the German accounting literature that use data directly from commercial registers show that compliance with public disclosure requirements was minimal (approximately 10\%) prior to the enforcement change, but improved dramatically (to approximately 90\%) thereafter (e.g., Henselmann and Kaya, 2009). These proportions of compliance map closely to the increase in available observations on Amadeus in 2004 versus 2006 and onward (see Table 3 Panel B in Bernard et al., 2015), suggesting that the improved data availability is primarily due to firms' improved compliance with public disclosure requirements, not a decision by Amadeus to dramatically change its data coverage. ${ }^{20}$

I proxy for financial constraint using the industry-adjusted book leverage of the firm net of cash holdings (that is, the firm's total debt net of cash, scaled by the firm's total assets, minus the average of this ratio for all firms in the same 4-digit NAICS code). A number of results in prior work motivate this proxy. First, there is robust and consistent evidence that, on average, a firm's observable leverage is positively related to its financial constraint, incremental to the effect of several other determinants, such as size, operating performance, and firm age. Although some prior papers form linear combinations of these firm-level variables to measure financial constraint (e.g., Whited and Wu, 2006), I do not follow such an approach because some variables necessary to construct these measures (such as Tobin's Q) are unavailable for the firms in my sample. Nonetheless, I note that prior archival, survey, and analytical papers underscore the

\footnotetext{
${ }^{20}$ To provide additional evidence that the results presented below are not due to a database coverage issue, I estimate an analog of Equation (1) for UK limited liability private firms. Mandatory disclosure requirements have been enforced in the UK since the 1960s, and if there were a change in data coverage on Amadeus between 2004 and 2006, presumably it would not be limited to German firms. After imposing selection criteria for UK private firms analogous to those described below for German firms, I obtain a sample of 38,532 observations. Untabulated results show that prior disclosure avoidance is extremely uncommon among UK private firms and has no significant relation with financial constraint.
} 
importance of leverage as a key determinant of financial constraint. Hadlock and Pierce (2010) and Kaplan and Zingales (1997) find that leverage is strongly positively related to the probability that public firm managers make qualitative disclosures in SEC filings indicating financial constraint, and Whited and $\mathrm{Wu}$ (2006) and Lamont et al. (2001) positively weight leverage in constructing parsimonious models of financial constraint. Graham and Harvey (2001) show that managers view financial flexibility as decreasing in debt. In a similar vein, a number of analytical papers suggest that high levels of leverage impede a firm's willingness to undertake investment opportunities due to the "debt overhang" problem (e.g., Myers, 1977). ${ }^{21}$

Second, by deducting cash holdings from the total debt of the firm, the measure accounts for prior evidence that cash holdings reduce the firm's financial constraint (Fresard, 2010; Haushalter et al., 2007; Kaplan and Zingales, 1997). Third, by adjusting the book leverage of the firm (net of cash) by the industry average, I subtract industry-level factors that could account for cross-sectional differences in leverage ratios and cash holdings. This approach is consistent with a number of prior papers that study capital structure-product market interactions (e.g., Campello, 2006) as well as the intuition that financial constraint (a firm's ability to fund its current and future operations) is partly determined by rivals' financing decisions.

Equation (1) also includes a number of variables to control for other benefits and costs of disclosure. I control for the firm's relative operating profitability using the firm's industryadjusted operating return-on-assets (i.e., operating earnings scaled by total assets, minus the average of this ratio for all firms in the same 4-digit NAICS code). This measure is included to account for evidence in prior literature that, on average, better performing firms face greater

\footnotetext{
${ }^{21}$ Prior papers also provide evidence that predation risk is increasing in the leverage of the firm relative to rivals (Zingales, 1998; Chevalier, 1995; Lerner, 1995). However, these papers do not explicitly show that financial constraint is the mechanism for this relation.
} 
proprietary costs of disclosure of financial statement information (Dedman and Lennox, 2009; Botosan and Stanford, 2005). Controlling for relative operating profitability is also important given the strong negative relation between leverage and operating performance documented in the capital structure literature (e.g., Lemmon et al., 2008). To proxy for the higher proprietary costs faced by firms that depend more on patents, licenses, customer lists, and other intangible assets (Ellis et al., 2012), I also control for the firm's level of intangibility using the book value of intangible assets scaled by total assets.

I include controls for two potentially important dimensions of industry competition public firm presence and market concentration. I proxy for the presence of a public rival using an indicator variable that equals one if there is at least one public German company in the firm's 4digit NAICS code. This measure is intended to account for (1) the presence of competitors with fewer financing frictions than private firms (Brav, 2009), and (2) higher investment sensitivity in the industry (Badertscher et al., 2013). I include the measure of public firm presence as a main effect (as well as an interactive effect in the cross-sectional tests below) because greater investment sensitivity plausibly raises proprietary costs of disclosure across all firms.

To control for market concentration, I construct the Herfindahl-Hirschman index formed by 4-digit NAICS code using total assets of German firms with publicly disclosed financial statement information (i.e., including private limited liability companies and public firms). I use total assets instead of sales because small and medium-sized private firms in Germany are not required to disclose sales. Ali et al. (2009) show that incorporating private firm data is critical to proxy for market concentration, consistent with the importance of private firms to economic activity in the US and Europe (Badertscher et al., 2013; Minnis, 2011; Allee and Yohn, 2009). Nonetheless, measures of market concentration are controversial in studies of proprietary 
disclosure costs for a number of conceptual and empirical reasons (Lang and Sul, 2014; Dedman and Lennox, 2009), so I include the measure mainly for completeness and make no prediction on its directional effect.

The remaining controls include a measure of firm size, the natural log of total assets, as larger firms are likely to have more counterparties, a characteristic that reduces the likelihood that information disclosed in the contracting process remains proprietary (Dedman and Lennox, 2009). I control for the effects of high labor law enforcement using an indicator variable that equals one for firms in industries that may face additional pressure to publicly disclose important firm information due to greater regulatory scrutiny under German labor laws, and zero otherwise. ${ }^{22}$ I also include an indicator variable that equals one if the firm fails to report sales, and zero otherwise, as medium-sized German firms that choose to not report sales reveal a preference for nondisclosure. Missing sales data can reflect certain proprietary disclosure costs and other costs of disclosure that the setting does not fully rule out, such as the personal or social preference of an owner-manager to publicly disclose as little as possible. Finally, I include an indicator variable that equals one (zero) for firms in East (West) Germany, to control for potential differences in disclosure avoidance between historical East and West Germany; a control for the 2006 mean disposable income (in thousands) of the district in which the firm is located to account for differences in economic development across Germany; and a control for the year the firm was incorporated to account for the fact that more tends to be publicly known about older firms (Dedman and Lennox, 2009). ${ }^{23}$

\footnotetext{
22 This control variable equals one for firms in the forestry, construction, transportation, hospitality, animal processing, and facilities services industries - that is, firms in the 3-digit NAICS codes 113, 236, 237, 238, 481, 482, 483, 484, 485, 486, 487, 488, 721, and 722, as well as the 4-digit NAICS codes 3116, 5612, and 5617. Historically, German firms in these industries have been more likely to employ "undocumented" or "informal" labor. See: www.ilo.org/wcmsp5/groups/public/---ed_dialogue/---lab_admin/documents/genericdocument/wcms_116069.pdf. ${ }^{23}$ Although I expect the proxies for relative operating profitability, size, and firm age to capture important costs or benefits of disclosure unrelated to predation risk, some prior papers do provide evidence that these variables are
} 
All continuous variables are winsorized at the $1^{\text {st }}$ and $99^{\text {th }}$ percentiles to minimize the influence of outliers, and then standardized to have a mean of zero and a standard deviation of one to allow for easier comparison across regression coefficients. Hypotheses $1 \mathrm{a}$ and $1 \mathrm{~b}$ predict the coefficients $\beta_{1}$ and $\beta_{2}$ are significantly positive, respectively.

\section{5: Sample selection and descriptive statistics}

\section{1: Sample selection}

I select observations of German firms on Amadeus with fiscal year ends between December 31, 2006 and December 30, 2007 - the first annual period the "EHUG" enforcement regime was in effect. I exclude non-limited liability legal forms, as public disclosure requirements generally do not apply to these entities, and I exclude observations without basic data on the firm's industry (NAICS code), location, or year of incorporation.

I exclude firms that report total assets less than or equal to 4,015,000 euro, the "brightline" asset size threshold that demarcated small from medium-sized firms under German law in 2006 and 2007 (see Appendix). Small private firms in Germany are not required to be audited or disclose income statement information, but medium-sized and large private firms are required to be audited and disclose at least some income statement information. Thus, this selection choice (1) increases the probability that the financial statement disclosures of firms in the sample are audited and therefore reliable and (2) ensures that extremely small firms with limited public disclosure requirements do not drive the results.

Finally, I exclude observations missing financial statement data necessary for the empirical tests as well as firms incorporated in 2005 or later. The latter requirement ensures that

systematically associated with financial constraint (e.g., Hadlock and Pierce, 2010). As a result, I cannot guarantee that these proxies capture distinct constructs. However, it is not clear how this limitation could provide an alternative explanation for the paper's primary findings. 
all firms in the sample were required to file financials at least once prior to the implementation of the "EHUG" enforcement regime (e.g., this requirement ensures that a firm that first appears in Amadeus in 2005 because it incorporated in 2005 is not classified as a disclosure avoider). Table 1 shows that these sample selection criteria yield a final sample of 31,305 firm observations. ${ }^{24}$ $<$ TABLE $1>$

\section{2: Descriptive statistics}

Table 2 shows basic descriptive statistics for the final sample. Panel A presents the mean level of disclosure avoidance prior to the enforcement change and the number of observations in the final sample by industry (two-digit NAICS code). Panel B presents summary statistics on the independent variables, including the continuous variables before they are each standardized to have a mean equal to zero and standard deviation equal to one. Panel C presents summary statistics on the continuous variables after standardization. Panel D presents Pearson correlations.

$<$ TABLE $2>$

The results in Panel A show that 55\% of firms did not disclose prior to the change in enforcement, which suggests disclosure avoidance among firms in the sample is neither extremely rare nor extremely common. The level of disclosure avoidance varies across industries, ranging from a low of $28 \%$ for utilities to a high of $62 \%$ for retailers. The results in Panels B and C highlight substantial variation in the independent variables. The interquartile

\footnotetext{
${ }^{24}$ Bureau van Dijk deletes all firm-year observations on Amadeus for firms that fail to file financial statements for four consecutive years (e.g., because the firms went bankrupt and liquidated). Although this deletion process has the effect of reducing the sample size in the earlier years of the sample, but not in the most recent years, it is unlikely to explain the paper's findings, given that I examine disclosure decisions of firms prior to the enforcement change conditional on each firm's inclusion in the dataset for its fiscal year-end between December 31, 2006 and December 30, 2007. Thus, while it is likely that more financially constrained firms are missing from the dataset to the extent high financial constraint is associated with bankruptcy, it is not clear how this lack of data availability would induce the empirical relations I predict for firms that are in the dataset for fiscal year-ends between December 31, 2006 and December 30, 2007.
} 
range of industry adjusted leverage net of cash is $0.39,{ }^{25}$ and the interquartile range of industry adjusted ROA is 0.12 (that is, $12 \%$ ). The statistics also show that at least $90 \%$ of firms in the sample were incorporated by 2002, suggesting the vast majority of firms faced nominal public disclosure requirements for multiple years before the enforcement change. Finally, the results in Panel D show a relatively strong negative correlation $(-0.21)$ between industry adjusted ROA and industry adjusted leverage net of cash, a result that is broadly consistent with evidence in the capital structure literature that operating performance and leverage are negatively related (e.g., Myers, 1993).

\section{6: Results}

\section{1: Determinants of disclosure avoidance (H1)}

Table 3 presents the results of estimating Equation (1) using ordinary least squares. I use a linear probability model so the model coefficients presented throughout the paper are interpretable as marginal effects (see e.g., Ai and Norton, 2003), though I emphasize that the results are inferentially identical when I use a binary (e.g., probit or logit) model instead.

Columns 1 - 3 exclude the squared leverage term that is included in columns 4 - 6 . Columns 1 and 4 exclude all control variables, columns 2 and 5 include all control variables except those likely to reflect proprietary disclosure costs, and columns 3 and 6 include the complete set of control variables.

The results present consistent, significant evidence that financial constraint has a positive quadratic relation with disclosure avoidance, consistent with $\mathrm{H} 1 \mathrm{a}$ and $\mathrm{H} 1 \mathrm{~b}$. Table 3 shows that the coefficients on the linear and quadratic terms for industry adjusted leverage net of cash are

\footnotetext{
${ }^{25}$ The mean of book leverage net of cash, without industry adjustment, is approximately 0.59 (untabulated), consistent with prior evidence that private firms are relatively more levered than public firms (Brav, 2009).
} 
positive and statistically significant in each of the models, and the results are generally more significant when control variables are added. ${ }^{26}$

$<$ TABLE 3>

Figure 2 plots estimated margins and corresponding 95\% confidence intervals for [-3 standard deviations, +3 standard deviations] of financial constraint based on the estimation of Equation (1) in Table 3, column 6. The results suggest that moving from -1 standard deviation of financial constraint (mean financial constraint) to +1 standard deviation of financial constraint ( +2 standard deviations of financial constraint) results in a roughly $3.7(8.3)$ percentage point increase in the likelihood of prior disclosure avoidance.

\section{$<$ FIGURE 2>}

Figure 3 provides a visual representation of the estimated margins and corresponding $95 \%$ confidence intervals for [ -3 standard deviations, +3 standard deviations] of four control variables (relative operating profitability, intangibility, market concentration, and firm size) that are widely studied in prior literature on proprietary disclosure costs (Ellis et al., 2012; Bens et al., 2011; Dedman and Lennox, 2009; Botosan and Stanford, 2005). Based on the estimation of Equation (1) in Table 3, column 6, a two standard deviation increase in relative operating profitability (intangibility) increases the likelihood of disclosure avoidance by 3.3 (1.5) percentage points, whereas a two standard deviation increase in market concentration (firm size) decreases the likelihood of disclosure avoidance by $2.0(8.0)$ percentage points. Overall, the effect of financial constraint on disclosure avoidance appears to be economically significant.

\section{$<$ FIGURE 3 $>$}

\footnotetext{
${ }^{26}$ The pseudo $\mathrm{R}^{2}$ 's for probit estimations of the fully specified models in this paper are generally $5-5.5 \%$, which are slightly lower than but generally consistent with the pseudo $\mathrm{R}^{2}$ 's reported in prior studies of disclosure avoidance. For example, the pseudo $\mathrm{R}^{2}$ 's reported in Dedman and Lennox's (2009) models of disclosure avoidance are generally $7-8 \%$.
} 
The coefficient estimates on the remaining control variables in Table 3 are mostly consistent with my predictions. I find that firms in industries subject to greater regulatory scrutiny under German labor laws are less likely to have avoided financial statement disclosure; firms that do not disclose sales are more likely to have avoided disclosure; and firms incorporated more recently are more likely to have avoided disclosure. Interestingly, the results also show that East German firms are significantly less likely than West German firms to avoid disclosure, even after controlling for average income by district. ${ }^{27}$

\section{2: Cross-sectional evidence of predation risk on disclosure decisions (H2 - H5)}

Equation (2) is used to test hypotheses 2-5:

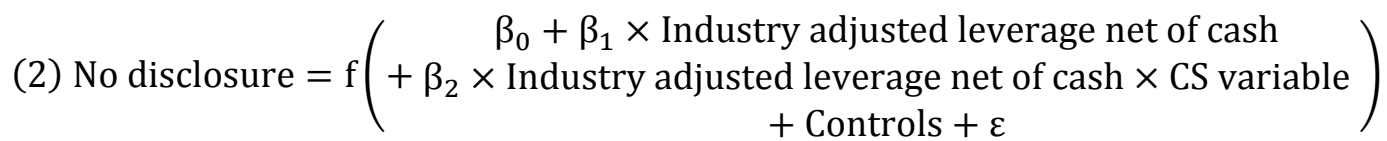

There are two differences between Equation (1) and Equation (2). First, I drop the quadratic term for industry adjusted leverage net of cash from the specification to avoid including interactions with quadratic terms. Including interactions with quadratic terms would force the relation between financial constraint and disclosure avoidance to be quadratic even at representative values of the cross-sectional variables where I do not expect the relation to be quadratic (e.g., for firms substantially larger than rivals).

Second, I add the interaction of industry adjusted leverage net of cash with crosssectional variables that proxy for relative size (industry adjusted natural log of total assets),

\footnotetext{
${ }^{27}$ I conduct a number of tests to examine the robustness of the results in Section 6.1 to several data and model adjustments. I find the results remain significant and consistent with $\mathrm{Hla}$ and $\mathrm{H} 1 \mathrm{~b}$ when (1) disclosure avoidance is modeled using either a logit model or a probit model (using either average marginal effects or marginal effects "at means"), (2) financial and public administration firms (firms in NAICS codes 52 or 92) are dropped from the sample, (3) industry adjusted leverage net of cash is truncated instead of winsorized at the $1^{\text {st }}$ and $99^{\text {th }}$ percentiles, (4) industry level is defined using 3-digit NAICS codes instead of 4-digit NAICS codes, (5) industry fixed effects or quadratic terms for operating profitability or size are included in the model, (6) cash holdings are not subtracted from total debt in forming industry adjusted leverage net of cash, (7) the sample is limited to firms without a consolidation companion on Amadeus, or (8) standard errors are clustered at the 4-digit NAICS industry level.
} 
relative operating profitability (industry adjusted ROA), public firm presence (public rival), or the propensity for ex ante sales contracting (ex ante contracting). The interactive effects of each of these variables with industry adjusted leverage net of cash test H2 - H5. Industry adjusted ROA and public rival are defined as in Equation (1), and industry adjusted natural log of total assets is the natural log of total assets minus the average of this variable by 4-digit NAICS code. Ex ante contracting equals one for firms in manufacturing industries (NAICS codes 31-33) that produce "differentiated products" based on the product homogeneity classification scheme in Rauch (1999), and zero otherwise. Using an indicator variable for manufacturing firms that produce differentiated products to proxy for the propensity to rely on "ex ante" sales contracts is based partly on Rajgopal et al. (2003) and Costello (2013), who show that order backlog and long-term supply contracts are particularly common among manufacturing firms. Rajgopal et al. (2003) show that more than $80 \%$ of firms with order backlog disclosures are in manufacturing industries, and Costello (2013) shows that firms in manufacturing industries make up roughly $69 \%$ of her sample of long-term supply contracts, even though manufacturing firms only constitute roughly $28 \%$ of the Compustat universe.$^{28}$ Nonetheless, because the propensity for "ex ante" sales contracting is likely muted for firms that produce more homogenous goods, ex ante contracting equals one only for manufacturing firms whose goods are not reference priced either in trade journals or on organized exchanges. ${ }^{29}$

\footnotetext{
${ }^{28}$ Long-term contracting is especially common in German manufacturing industries. For example, Lane and Bachman (1996) examine supplier relations in Britain and Germany in two manufacturing industries. They write that, "[i]n Germany, long-term relations with customers and suppliers are the rule... German managers not only show a stronger commitment to long-term relationships, but are also significantly more likely to enter into long-term contracts. Whereas a mere 9 percent of German firms have only short-term repeat contracts, 61 percent of British firms indicated that they only favour repeat contracts." Burchell and Wilkinson (1997) reach a similar conclusion, noting that the motives for long-term relationships in Germany include "security, strategic reasons, specific investment and the exchange of confidential information."

${ }^{29}$ Rauch (1999) classifies traded goods as "differentiated products," "reference priced," or "homogenous goods" separately by SITC code. Because the mapping between SITC codes and NAICS codes is not one-to-one, I approximate the level of product homogeneity for each NAICS code by assigning a value of two to SITC codes with
} 
Table 4 presents the full results of estimating Equation (2), where, due to the inclusion of the interactions, I do not make a prediction regarding the sign of the main effect of financial constraint. For expositional convenience, I focus the discussion of results on Figure 4, where I plot estimated margins and corresponding 95\% confidence intervals for [-3 standard deviations, +3 standard deviations] of financial constraint at representative values of the cross-sectional variables, based on the estimates presented in columns 1 - 4 in Table 4. For the tests of H2 (Panel A) and H3 (Panel B), I separately plot estimated margins at the $10^{\text {th }}$ and $90^{\text {th }}$ percentiles of relative size and relative operating profitability, respectively. For the test of H4 (Panel C), I separately plot estimated margins for firms without and with public rivals. For the test of H5 (Panel D), I separately plot estimated margins based on the firm's propensity to rely on ex ante sales contracts.

\section{$<$ TABLE 4>}

The results plotted in Figure 4 are strongly consistent with hypotheses H2 - H5. Panel A shows that the positive relation between financial constraint and disclosure avoidance is concentrated among firms that are smaller than industry rivals; this result is consistent with prior papers that find that relatively small firms are more common targets for predation, ceteris paribus (e.g., Scott Morton, 1997; Chevalier, 1995). Panel B provides evidence that, consistent with prior work, the proprietary costs of disclosure for more profitable firms are greater on average than the proprietary costs of disclosure for less profitable firms (e.g., Dedman and Lennox, 2009).

However, Panel B also shows that the probability of disclosure avoidance is not statistically different among relatively profitable and relatively unprofitable firms at high levels of financial

\footnotetext{
"homogeneous goods," a value of one to SITC codes with goods that are "reference priced," and a value of zero to "differentiated products." I then find the median value across the SITC codes that correspond to each NAICS code (based on the "conservative" classification scheme in Rauch (1999)). Ex ante contracting equals one for firms in manufacturing industries for which this median value equals zero.
} 
constraint, consistent with the hypothesis that predation risk imposes additional costs of disclosure for relatively unprofitable firms with high levels of financial constraint. ${ }^{30}$ Panel C shows that the effect of financial constraint on disclosure avoidance is stronger among firms that operate in industries that include at least one public firm, consistent with higher predation risk in industries with (1) at least one relatively sophisticated rival with easier access to external financing (Brav, 2009), and (2) lower investment uncertainty (Badertscher et al., 2013). Finally, Panel D shows that the positive relation between disclosure avoidance and financial constraint is significantly muted among firms that are more likely to rely on ex ante sales contracts. This result is consistent with the idea that ex ante sales contracts can lower the benefits and raise the costs for competitors to prey (e.g., Scott Morton, 1997).

In column 5 of Table 4, I include all four of the interactions in a single regression to test whether any of the cross-sectional effects is subsumed by the others. The coefficients on all of the interactions remain significant in the predicted direction.

$$
<\text { FIGURE } 4>
$$

\section{3: Supplemental tests}

In this section, I present the results of three sets of supplemental tests. In Section 6.3.1, I take advantage of the stepwise increase in filing compliance between 2004 and 2006 to

\footnotetext{
${ }^{30}$ One possible interpretation of the results in Figure 4 Panels A and B is that relative size and relative operating profitability merely refine the measure of financial constraint. Put differently, the cross-sectional tests in Panels A and B may only capture differences across firms in the levels of size and operating profitability - determinants of financial constraint (Campello et al., 2010; Hadlock and Pierce, 2010) - rather than relative-to-rival differences per se, which are also important to the predictions in $\mathrm{H} 2$ and $\mathrm{H} 3$. In untabulated tests, I add the interaction of industry adjusted leverage net of cash and the natural $\log$ of total assets to the estimation in Table 4, column 1 and the interaction of industry adjusted leverage net of cash and ROA to the estimation in Table 4, column 2, where ROA equals the operating profitability of the firm scaled by total assets, without industry adjustment. If the cross-sectional tests for relative size and relative operating profitability are only refining the measure of financial constraint, then these additional interactions should subsume the original interactions. In fact, I find that the original interactions remain statistically significant in the predicted directions $(\mathrm{p}<0.01, \mathrm{p}<0.10$, respectively), consistent with the relative-to-rival adjustments being important to these cross-sectional tests.
} 
determine whether firms more vulnerable to predation waited longer to disclose. In Section 6.3.2, I examine the cross-sectional effect of two dimensions of market structure on the relation between disclosure avoidance and financial constraint. In Section 6.3.3, I examine ex post evidence of predation.

\subsection{1: First disclosure and the determinants of disclosure avoidance}

If firms subject to relatively high levels of predation risk deferred public disclosure of financial statement information as late as possible, the relation between financial constraint and disclosure avoidance should be stronger for firms that first filed for their fiscal years ending between December 31, 2006 and December 30, 2007 compared to firms that first filed for their fiscal years ending between December 31, 2005 and December 30, 2006. However, one potential limitation in empirical tests of this prediction is that the firms that waited to disclose as late as possible were also most likely to implement financing actions to reduce their financial constraint and thereby mitigate predation risk (Haushalter et al., 2007).

In Table 5 column 1, Equation (1) is re-estimated excluding firms that first file December 31, 2006 - December 30, 2007; in column 2, Equation (1) is re-estimated excluding firms that first file December 31, 2005 - December 30, 2006. Thus, whereas column 1 compares the characteristics of firms that first file December 31, 2005 - December 30, 2006 against those that did not avoid disclosure, column 2 compares the characteristics of firms that first file December 31, 2006 - December 30, 2007 against those that did not avoid disclosure. As expected, the coefficients on the linear and quadratic terms for industry adjusted leverage net of cash are positive and significant in both estimations. I use chi-square tests to examine the equality of these coefficients between the two estimations. While the coefficient on the linear term for industry adjusted leverage net of cash is not statistically different between estimations $(\mathrm{p}=0.45)$, 
the coefficient on the quadratic term is significantly larger in column 2 than column $1(\mathrm{p}<0.01)$, consistent with a stronger quadratic relation for the later disclosers.

$<$ TABLE 5>

\subsection{2: Dimensions of market structure and disclosure avoidance}

This section presents the results of cross-sectional tests related to two dimensions of industry market structure. The first is product substitutability. High levels of product substitutability can lower the costs of predation for the predator, as firms in industries with high product substitutability can simply cut prices to capture business from a targeted competitor. In contrast, firms need to make a variety of specific investments (in intellectual property, machinery and other equipment, human capital, sales relationships, etc.) to prey on the producer of a highly differentiated product. This intuition is supported by prior evidence that suggests that predation risk is higher when firms have more similar operations and share growth opportunities (Haushalter et al., 2007). Thus, I expect the relation between disclosure avoidance and financial constraint is stronger in industries with higher levels of product substitutability.

The second dimension of market structure relates to entry costs. High costs of entry can raise predation risk, as predation is more likely when entrants cannot easily compete away abnormal profits that a predator might otherwise earn after preying on rivals (Bolton et al., 2000; Ordover and Willig, 1981). To the extent predation is predominately motivated by incentives to build and maintain high levels of market power (as opposed to, say, incentives to acquire rivals at lower cost), the relation between disclosure avoidance and financial constraint should be stronger in industries with higher costs of entry.

Because sales are not available for a meaningful proportion of the observations in my sample, I calculate an adjusted form of the Lerner Index to proxy for product substitutability. 
Specifically, I proxy for product substitutability as the negative of the weighted-average operating return-on-assets of firms by 4-digit NAICS code, where weights are based on firm size (total assets). I proxy for costs of entry as the weighted-average capital intensity of firms by 4digit NAICS code, calculated as the weighted-average ratio of fixed assets to total assets. ${ }^{31}$ I then separately estimate Equation (2) using the proxies for product substitutability and costs of entry as cross-sectional variables.

The results are presented (with the coefficients on the control variables omitted for brevity) in Table 6 . I find that the interaction the interaction of substitutability and industry adjusted leverage net of cash is positive and statistically significant $(\mathrm{p}<0.01)$, consistent with a stronger relation between disclosure avoidance and financial in industries with higher levels of product substitutability. I also find that the interaction of cost of entry and industry adjusted leverage net of cash is positive and statistically significant $(p<0.05)$, consistent with a stronger relation between disclosure avoidance and financial constraint in industries with greater costs of entry. To test the robustness of these results, I add both of these interactions to the model estimated in Table 4, column 5. I find that the interaction of substitutability and industry adjusted leverage net of cash remains significantly positive, the interaction of cost of entry and industry adjusted leverage net of cash becomes statistically insignificant, and the interactions of the main cross-sectional variables (discussed in Section 3.2) with industry adjusted leverage net of cash remain significant in the predicted directions.

$<$ TABLE 6>

\footnotetext{
${ }^{31}$ See Bens et al. (2011) and Karuna (2007) for similarly constructed measures of product substitutability and costs of entry. Results are not sensitive to using the log of the average level of fixed assets by 4-digit NAICS code as an alternative proxy for costs of entry.
} 


\subsection{3: Financial constraint, disclosure avoidance, and ex post performance}

Although the empirical analyses above examine ex ante evidence of disclosure avoidance to mitigate predation risk, it is also possible to examine evidence of predation subsequent to the "forced" disclosure of private firm financial statements. I emphasize ex ante evidence in the main analyses for two reasons. First, even a small risk of predation could be sufficient to lead an owner-manager to avoid disclosure, so the ex post rate of predation is likely to be substantially lower (and more difficult to detect) than the ex ante rate of disclosure avoidance to mitigate predation risk. Second, the timing of the enforcement change in Germany means that ex post evidence of predation necessarily coincides with the 2008 financial crisis and ensuing recession. Differentiating predatory effects from the effects of the broader macroeconomic downturn is empirically challenging. The tests below should be interpreted with these limitations in mind.

Nonetheless, ex post evidence may serve to reinforce the ex ante findings and shed more light on the real effects of private firm disclosure decisions. Thus, to examine ex post evidence of predation, I estimate the following equation using ordinary least squares:

(3) Ex post performance $=\mathrm{f}\left(\begin{array}{c}\beta_{0}+\beta_{1} \times \text { Industry adjusted leverage net of cash } \\ +\beta_{2} \times \text { Industry adjusted leverage net of cash } \times \text { No disclosure } \\ +\beta_{3} \times \text { No disclosure }+ \text { Controls }+\varepsilon\end{array}\right)$ I examine four measures of ex post performance: a binary variable equal to one if the firm remains on the Amadeus database in the post period, and zero otherwise; the percentage change in cash holdings; the percentage change in fixed assets; and the percentage change in industry market share (measured based on total assets and 4-digit NAICS codes). These proxies capture changes in observable performance along multiple dimensions examined in prior literature on predation, including the firm's liquidity, capital base, and market share (e.g., Haushalter et al., 2007; Campello, 2006; Chevalier, 1995). I include the binary survival proxy to capture the most 
extreme outcomes of predation (i.e., bankruptcy and liquidation), although I caution that the measure is imperfect in that other factors, such as legal form changes, can also cause a firm's subsequent exclusion from the Amadeus database. Each variable is measured between the firm's filing between December 31, 2006 and December 30, 2007 and its filing (or lack thereof) two or three years later, and each continuous dependent variable is replaced with its decile rank to minimize the effects of outliers. ${ }^{32}$ The control variables in Equation (3) include measures of the firm's size (the natural log of total assets), year incorporated, and tangibility, which equals the ratio of fixed assets to total assets (e.g., Zingales, 1998). The controls also include an indicator variable that equals one for firms with negative operating profitability and a measure of the median income of the district in which the firm is located.

The primary empirical prediction is $\beta_{2}<0$; if firms avoided mandated disclosure of financial statement information because of predation risk, financial constraint should be more negatively associated with the probability of survival and changes in liquidity, capital base, and market share following the enforcement change for firms that previously avoided disclosure. Table 7 presents the results of this analysis. The estimated coefficients on the interactions of industry adjusted leverage net of cash and no disclosure are negative and statistically significant for at least one period for three of the four measures. Overall, the results are consistent with greater liquidity problems, reduced fixed assets (e.g., due to asset dispositions), and more market

\footnotetext{
${ }^{32}$ Prior papers in the German accounting literature show that most private firms wait as long as possible (that is, 12 months after fiscal year end) to publicly disclose their financial statements (e.g., Bauer and Bigus, 2014; Kaya, 2010). Indeed, there is some evidence that a small proportion of firms incurred significant penalties to delay disclosure even beyond the 12 month filing deadline after the "EHUG" enforcement regime initially began (e.g., Henselmann and Kaya, 2009). Because disclosure is typically lagged by at least 12 months for German private firms (so competitors cannot observe the firm's financial information for at least one year after the fiscal year end), ex post measures of performance are measured over the two or three years following the enforcement change. The three year period test is motivated by prior papers that show that predation sometimes takes several years to play out (Zingales, 1998; Lerner, 1995).
} 
share losses among firms that first disclose their financials due to the enforcement change. ${ }^{33}$

However, there is no evidence that the survival rate of firms is lower for more financially

constrained firms that previously avoided disclosure compared to those that previously disclosed.

This result could reflect the fact that predation results in a variety of outcomes (market share

losses, exit from a specific segment, etc.), where bankruptcy is the most extreme and likely the

least frequent. The null result could also be partly due to error in measuring failure based on data availability in the Amadeus database or noise introduced by the concomitant effects of the financial crisis and ensuing recession. ${ }^{34}$

\section{$<$ TABLE 7>}

The analyses provide several other interesting results. First, I find that the main effect of disclosure avoidance is negative and significant (i.e., $\beta_{3}<0$ ) in the survival, fixed asset and market share tests, consistent with mandated financial statement disclosure imposing proprietary costs on disclosing firms. These proprietary costs could include predation to the extent predation facilitated by the enforcement change does not strictly target more financially constrained firms. Second, I find that while the main effect of financial constraint has a significantly negative relation with ex post survival and changes in fixed assets and market share (e.g., Zingales, 1998), I find that it has a significantly positive relation with changes in cash holdings. This result is consistent with more financially constrained firms (specifically, those financially constrained

\footnotetext{
${ }^{33}$ In untabulated results, I also find that this interaction is negative and significant when I use the percentage change in total assets (over either the subsequent two or three years) as the dependent variable.

${ }^{34}$ In untabulated tests I use UK limited liability firms as an alternative control group in Equation (3) (that is, in place of German private firms that did not avoid disclosure prior to the enforcement change). When I replace no disclosure in Equation (3) with UK firm, an indicator variable for UK limited liability firms that meet analogous sample selection criteria as those required for German limited liability firms in the main analyses, I find that the interaction of UK firm and industry adjusted leverage net of cash is positive and statistically significant for each dependent variable and ex post period examined in Table 7 . Though these results should be interpreted with caution due to differences in capital financing practices and macro-economic conditions between the UK and Germany, they are consistent with the relation between financial constraint and ex post outcomes being worse for German firms that previously avoided disclosure than otherwise similar UK firms that did not face a change in disclosure enforcement.
} 
firms that did not go bankrupt or leave the sample for other reasons) using asset sales and other capital sources to raise cash in response to the crisis.

\section{4: Discussion of alternative interpretations}

The results above show that financial constraint is positively associated with disclosure avoidance, and this relation is generally stronger for firms with characteristics that are likely to be related to higher levels of predation risk. Overall, this evidence is consistent with the risk of predation imposing an important cost of disclosure on financially constrained firms. However, alternative interpretations of the evidence cannot be fully ruled out. In this section, I briefly discuss some of these alternative interpretations and their relation to my hypotheses.

One possibility is that industry adjusted leverage net of cash is capturing a construct other than financial constraint. For example, one complication with this proxy could be that observable leverage ratios are endogenous and likely reflect a variety of firm characteristics related to the borrowing capacity of the firm (e.g., Lemmon et al., 2008). However, it is not clear what alternative construct the proxy captures if not financial constraint, particularly given the crosssectional evidence that suggests the relation between disclosure avoidance and financial constraint depends strongly on other factors that also determine predation risk. Moreover, the proxy is negatively related to several performance outcomes, including the probability of survival and changes in market share (e.g., Zingales, 1998). These results are consistent with industry adjusted leverage net of cash capturing the firm's financial constraint, on average.

Another possibility is that managers of financially constrained firms avoid public disclosure to external parties other than competitors. For example, it is conceivable that managers avoid public disclosure in an attempt to hide negative information about the firm's performance or financial position from firm counterparties, consistent with prior evidence that 
high levels of indebtedness worsen terms of trade and turn off customers (Opler and Titman, 1994; Maksimovic and Titman, 1991). Although this "counterparty" explanation could partly explain the relation between disclosure avoidance and financial constraint, there are three reasons to doubt that it is the dominant effect. First, some counterparties, such as employees represented by a works council, have well-enforced information rights under German law, so they are unlikely to rely on public disclosures. Second, it is unclear why firms that are small or unprofitable relative to competitors or in industries with public competitors would be significantly more likely to attempt to hide negative information from counterparties. Third, the "counterparty" explanation fails to account for ex ante contracting incentives. It is unlikely that a rational counterparty would enter a material contract without first obtaining some assurance regarding the firm's financial health. Similarly, a counterparty (such as a creditor) is likely to demand periodic, ongoing assurance regarding the firm's financial health to mitigate ex post risks of moral hazard. If a firm chooses to avoid public disclosure, its counterparties are likely to demand private disclosure, and the firm's refusal to privately convey financial statement information or provide other assurance would itself be informative (e.g., Grossman, 1981). In this way, high levels of financial constraint can raise contracting costs even if the firm withholds public disclosure.

Other alternative explanations include the possibility that managers of highly financially constrained firms were simply too busy trying to survive to comply with disclosure requirements that were not enforced. This explanation is inconsistent with highly profitable firms being more likely to avoid disclosure and is difficult to reconcile with the cross-sectional tests. It is also possible that the relation between financial constraint and disclosure avoidance merely reflects the broad result in prior literature that poorly performing firms tend to disclose less (e.g., Miller, 
2002). This explanation typically stems from the idea that managers of better performing firms have capital market incentives to disclose more. However, it is not clear how this bears on the German private firm setting, where confidential financial statement disclosure to owners is required by law, so there is little incentive for firms to publicly disclose information to capital providers (e.g., Irani and Oesch, 2014).

\section{7: Summary and conclusions}

This paper provides evidence of a previously unexamined proprietary cost of disclosure: the risk of product market predation. The empirical analysis takes advantage of a setting in which (1) there are likely to be few non-proprietary costs of disclosure (such as agency costs) that could explain disclosure avoidance, (2) disclosed information is reliable, and (3) disclosure avoidance is likely to substantially affect the amount of financial information available to competitors. The

results show strong evidence of an increasingly positive relation between financial constraint and disclosure avoidance, and cross-sectional tests show that this relation is stronger for firms with other characteristics that are associated with higher levels of predation risk. Supplemental tests generally reinforce my interpretation of the results.

Collectively, the findings advance our understanding of the proprietary costs of financial statement disclosure and the determinants and consequences of predation risk. The evidence suggests that firms can minimize the proprietary cost associated with predation risk by avoiding disclosure and thereby imposing information asymmetries with potential predators. The results also suggest that the relation between profitability and proprietary costs depends on the firm's financial constraint and challenge the notion that disclosure of "negative" information does not impose proprietary costs (Tang, 2012; Bens et al., 2011). These findings are likely to be of 
interest to managers and regulators concerned about the competitive implications of mandatory disclosure regimes.

Future research can extend the findings in several ways. One promising avenue for future work is to further explore ex post evidence of predation, which would add to evidence on the real effects of accounting and disclosure decisions (e.g., Badertscher et al., 2013). Future research could explore the role of predation in the decision to go public, which is accompanied by extensive public disclosure requirements, or other disclosures of public companies that reveal important product market information. Future work could also explore whether the actions firms take to keep debt off the balance sheet are sometimes motivated by predation risk. 


\section{Appendix}

Disclosure and audit requirements in 2006 and 2007

This appendix summarizes the public disclosure and external audit requirements for German private limited liability firms in 2006 and 2007. Under the German Commercial Code, each firm is classified as small, medium, or large, and this size classification determines the disclosure and audit requirements imposed on the firm. Size classification is based on three variables: year-end total assets, annual sales, and average number of employees during the fiscal year. Firms are assigned to a larger size category when the values of two (or more) of the three size variables exceed "bright-line" thresholds set by the German government over two successive years. For example, a small firm moves up to become a medium firm as soon as at least two of three size variables exceed the threshold separating the small and medium size classifications for two consecutive years. Similarly, a medium firm does not move down to the small size class until at least two of three size variables remain below the small-medium size threshold for two consecutive years (Bernard et al., 2015). The small-medium "bright-line" size thresholds for German limited liability private firms in 2006 and 2007 were 4,015,000 euro in total assets, 8,030,000 euro in sales, and 50 employees. The medium-large "bright-line" size thresholds were 16,060,000 euro in total assets, 32,120,000 euro in sales, and 250 employees.

\section{$\underline{\text { Small firms }}$}

Balance sheet

Income statement

Notes

Director's report

External audit

\section{$\underline{\text { Medium firms }}$}

Balance sheet

Income statement

Notes

Director's report

External audit

\section{Large firms}

Balance sheet

Income statement

Notes

Director's report

External audit
Required in "abbreviated" format (e.g., several subcategories of items - such as current and long-term liabilities - can be aggregated)

Not required

Required in "abbreviated" format (items related to income statement accounts and details about balance sheet accounts can be omitted)

Not required

Not required

Required in "expanded abbreviated" format (e.g., few subcategories of items can be aggregated)

Required in "abbreviated" format (items such as sales, other operating income, and cost of materials can be aggregated to gross profit)

Required in "expanded abbreviated" format (certain items related to aggregated accounts can be omitted)

Required in full format

Required

Required in full format

Required in full format

Required in full format

Required in full format

Required 


\section{References}

Ai, C., Norton, E.C., 2003. Interaction terms in logit and probit models. Economics Letters 80, 123-129.

Ali, A., Klasa, S., Yeung, E., 2009. The limitations of industry concentration measures constructed with Compustat data: Implications for finance research. Review of Financial Studies 22, 3839-3871.

Allee, K.D., Yohn, T.L., 2009. The demand for financial statements in an unregulated environment: An examination of the production and use of financial statements by privately held small businesses. Accounting Review 84, 1-25.

Badertscher, B., Shroff, N., White, H., 2013. Externalities of public firm presence: Evidence from private firms' investment decisions. Journal of Financial Economics 109, 682-706.

Bauer, C., Bigus, J., 2014. Bank relationships and private firms' financial reporting opacity. Working Paper. Freie Universität Berlin.

Bens, D., Berger, P., Monahan, S., 2011. Discretionary disclosure in financial reporting: An examination comparing internal firm data to externally reported segment data. Accounting Review 86, 417-449.

Berger, P., 2011. Challenges and opportunities in disclosure research - A discussion of 'the financial reporting environment: Review of the recent literature.' Journal of Accounting and Economics 51, 204-218.

Bernard, D., Burgstahler, D., Kaya, D., 2015. Size management by European private firms to minimize disclosure and audit costs. Working Paper. University of Washington and University of Erlangen-Nürnberg. Available at: http://ssrn.com/abstract=2484161.

Bolton, P., Brodley, J.F., Riordan, M.H., 2000. Predatory pricing: Strategic theory and legal policy. Georgetown Law Journal 88, 2239-2330.

Bolton, P., Scharfstein, D., 1990. A theory of predation based on agency problems in financial contracting. American Economic Review 80, 93-106.

Botosan, C.A., Stanford, M., 2005. Managers' motives to withhold segment disclosures and the effect of SFAS No. 131 on analysts' information environment. Accounting Review 80, 751-771.

Brav, O., 2009. Access to capital, capital structure and the funding of the firm. Journal of Finance 64, 263-308.

Burchell, B., Wilkinson, F., 1997. Trust, business relationships and the contractual environment. Cambridge Journal of Economics 21, 217-237.

Burgstahler, D., Hail, L., Leuz, C., 2006. The importance of reporting incentives: Earnings management in European private and public firms. Accounting Review 81, 983-1016.

Burns, M., 1986. Predatory pricing and the acquisition cost of competitors. Journal of Political Economy 94, 266-296.

Campello, M., 2006. Debt financing: Does it boost or hurt firm performance in product markets? Journal of Financial Economics $82,135-172$.

Campello, M., Graham, J.R., Harvey, C.R., 2010. The real effects of financial constraints: Evidence from a financial crisis. Journal of Financial Economics 97, 470-487.

Chevalier, J.A., 1995. Do LBO supermarkets charge more? An empirical analysis of the effects of LBOs on supermarket pricing. Journal of Finance 50, 1095-1112.

Costello, A.M., 2013. Mitigating incentive conflicts in inter-firm relationships: Evidence from long-term supply contracts. Journal of Accounting and Economics 56, 19-39.

Dedman, E., Lennox, C., 2009. Perceived competition, profitability, and the withholding of information about sales and the cost of sales. Journal of Accounting and Economics 48, 210-230.

Dixit, A., Pindyck, R., 1994. Investment under uncertainty. Princeton University Press, Princeton.

Eberhartinger, E.L.E., 1999. The impact of tax rules on financial reporting in Germany, France, and the UK. The International Journal of Accounting 34, 93-119.

Eierle, B., Haller, A., Beiersdorf, K., 2007. Entwurf eines internationalen standards zur bilanzierung von small and medium-sized entities (ED-IFRS for SMES) - Ergebnisse einer befragung deutscher mittelständischer unternehmen. Berlin: BDI, DIHK, and DRSC.

Ellis, J.A., Fee, C.E., Thomas, S.E., 2012. Proprietary costs and the disclosure of information about customers. Journal of Accounting Research 50, 685-727.

Fresard, L., 2010. Financial strength and product market behavior: The real effects of corporate cash holdings. Journal of Finance $65,1097-1122$

Fudenberg, D., Tirole, J., 1986. A “signal-jamming” theory of predation. RAND Journal of Economics 17, 366-376.

Graham, J.R., Harvey, C.R., 2001. The theory and practice of corporate finance: Evidence from the field. Journal of Financial Economics 60, 187-243.

Grossman, S., 1981. The role of warranties and private disclosure about product quality. Journal of Law and Economics 24, 461483.

Hadlock, C.J., Pierce, J.R., 2010. New evidence on measuring financial constraint: Moving beyond the KZ index. Review of Financial Studies 23, 1909-1940.

Hanlon, M., Hoopes, J.L., Shroff, N., 2014. The effect of tax authority monitoring and enforcement on financial reporting quality. Journal of the American Taxation Association 36, 137-170.

Haushalter, D., Klasa, S., Maxwell, W.F., 2007. The influence of product market dynamics on a firm's cash holdings and hedging behavior. Journal of Financial Economics 84, 797-825. 
Henselmann, K., Kaya, D., 2009. Empirische analyse des offenlegungszeitpunkts von jahresabschlüssen nach dem EHUG. Die Wirtschaftsprüfung 62, 497-501.

Irani, R.M., Oesch, D., 2014. Financial constraints and corporate disclosure. Working Paper. University of Illinois at UrbanaChampaign and University of St. Gallen.

Kaplan, S.N., Zingales, L., 1997. Do investment-cash flow sensitivities provide useful measures of financing constraints? Quarterly Journal of Economics 112, 169-215.

Karuna, C., 2007. Industry product market competition and managerial incentives. Journal of Accounting and Economics 43 , 275-297.

Kaya, D., 2010. Strategien zur verminderung und vermeidung der jahresabschlusspublizität. Shaker, Aachen.

Lamont, O., Polk, C., Saá-Requejo, J., 2001. Financial constraints and stock returns. Review of Financial Studies 14, 529-544.

Lane, C., Bachmann, R., 1996. The social construction of trust: Supplier relations in Britain and Germany. Organization Studies $17,365-395$.

Lang, M., Sul, E., 2014. Linking industry concentration to proprietary costs and disclosure: Challenges and opportunities. Journal of Accounting and Economics 58, 265-274.

Lemmon, M.L., Roberts, M.R., Zender, J.F., 2008. Back to the beginning: Persistence and the cross-section of corporate capital structure. Journal of Finance 63, 1575-1608.

Lerner, J., 1995. Pricing and financial resources: An analysis of the disk drive industry, 1980-88. Review of Economics and Statistics 77, 585-598.

Maksimovic, V., Titman, S., 1991. Financial policy and reputation for product quality. Review of Financial Studies 4, $175-200$.

Milgrom, P., Roberts, J., 1982. Limit pricing and entry under incomplete information. Econometrica 50, 443-460.

Miller, G.S., 2002. Earnings performance and discretionary disclosure. Journal of Accounting Research 40, 173-204.

Minnis, M., 2011. The value of financial statement verification in debt financing: Evidence from private U.S. firms. Journal of Accounting Research 49, 457-506.

Myers, S.C., 1977. Determinants of corporate borrowing. Journal of Financial Economics 5, 147-175.

Myers, S.C., 1993. Still searching for optimal capital structure. Journal of Applied Corporate Finance 1, 4-14.

Opler, T.C., Titman, S., 1994. Financial distress and corporate performance. Journal of Finance 49, 1015-1040.

Ordover, J.A., Willig, R.D., 1981. An economic definition of predation: Pricing and product innovation. The Yale Law Journal 91, 8-53.

Porter, R.H., 2005. Detecting collusion. Review of Industrial Organization 26, 147-167.

Rajgopal, S., Shevlin, T., Venkatachalam, M., 2003. Does the stock market fully appreciate the implications of leading indicators for future earnings? Evidence from order backlog. Review of Accounting Studies 8, 461-492.

Rauch, J.E., 1999. Networks versus markets in international trade. Journal of International Economics 48, 7-35.

Scharfstein, D., 1984. A policy to prevent rational test-market predation. RAND Journal of Economics 15, 229-243.

Scott Morton, F., 1997. Entry and predation: British shipping cartels 1879-1929. Journal of Economics and Management Strategy 6, 679-724.

Shroff, N., Verdi, R.S., Yu, G., 2014. Information environment and the investment decisions of multinational corporations. Accounting Review 89, 759-790.

Szczesny, A., Valentinčič, A., 2013. Asset write-offs in private firms - The case of German SMEs. Journal of Business Finance \& Accounting 40, 285-317.

Tang, W.T., 2012. Proprietary costs of mandatory disclosure \& the decision to first access the public market. Working Paper. Georgetown University.

Vashishtha, R., 2014. The role of bank monitoring in borrowers' discretionary disclosure: Evidence from covenant violations. Journal of Accounting and Economics 57, 176-195.

Verrecchia, R.E., Weber, J., 2006. Redacted disclosure. Journal of Accounting Research 44, 791-814.

Watrin, C., Pott, C., Ullmann, R., 2012. The effects of book-tax conformity and tax accounting incentives on financial accounting: Evidence from public and private limited companies in Germany. International Journal of Accounting, Auditing, and Performance Evaluation 8, 274-302.

Weiman, D., Levin, R., 1994. Preying for monopoly? The case of the Southern Bell Telephone Company, 1894-1912. Journal of Political Economy 102: 103-126.

Whited, T.M., Wu, G., 2006. Financial constraints risk. Review of Financial Studies 19, 531-559.

Zingales, L., 1998. Survival of the fittest or the fattest? Exit and financing in the trucking industry. Journal of Finance 53, $905-$ 938. 
Figure 1

Evolution of the disclosure environment in Germany

This figure presents a timeline of significant events and law changes related to limited liability private firms' public disclosure requirements in Germany. The double vertical bars denote the passage of significant periods of time.

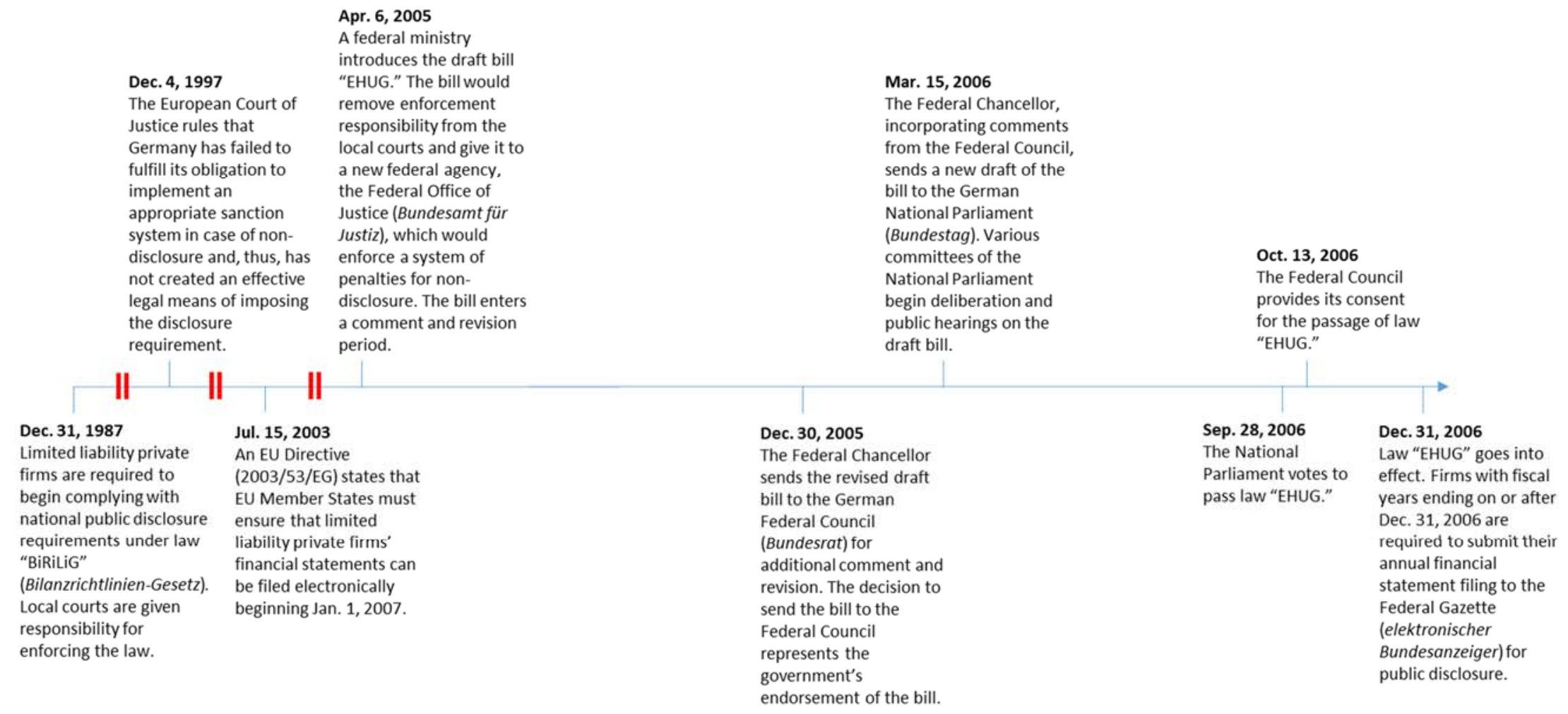


Figure 2

Disclosure avoidance and financial constraint

This figure plots estimated margins and corresponding 95\% confidence intervals of prior disclosure avoidance (no disclosure) for [-3 standard deviations, +3 standard deviations] of financial constraint (industry adjusted leverage net of cash). No disclosure is an indicator variable equal to one if the firm's first financial statement filing included in the Amadeus database is for its fiscal year end on or after December 31, 2005, and zero if before. Industry adjusted leverage net of cash equals the firm's total debt net of cash, scaled by total assets, minus the mean of this ratio for all other private limited liability firms in the same 4-digit NAICS code. All continuous variables are winsorized at the $1^{\text {st }}$ and $99^{\text {th }}$ percentiles and standardized to have a mean equal to zero and a standard deviation equal to one. Estimated margins are computed based on Equation (1), the results for which are presented in Table 3, column 6.

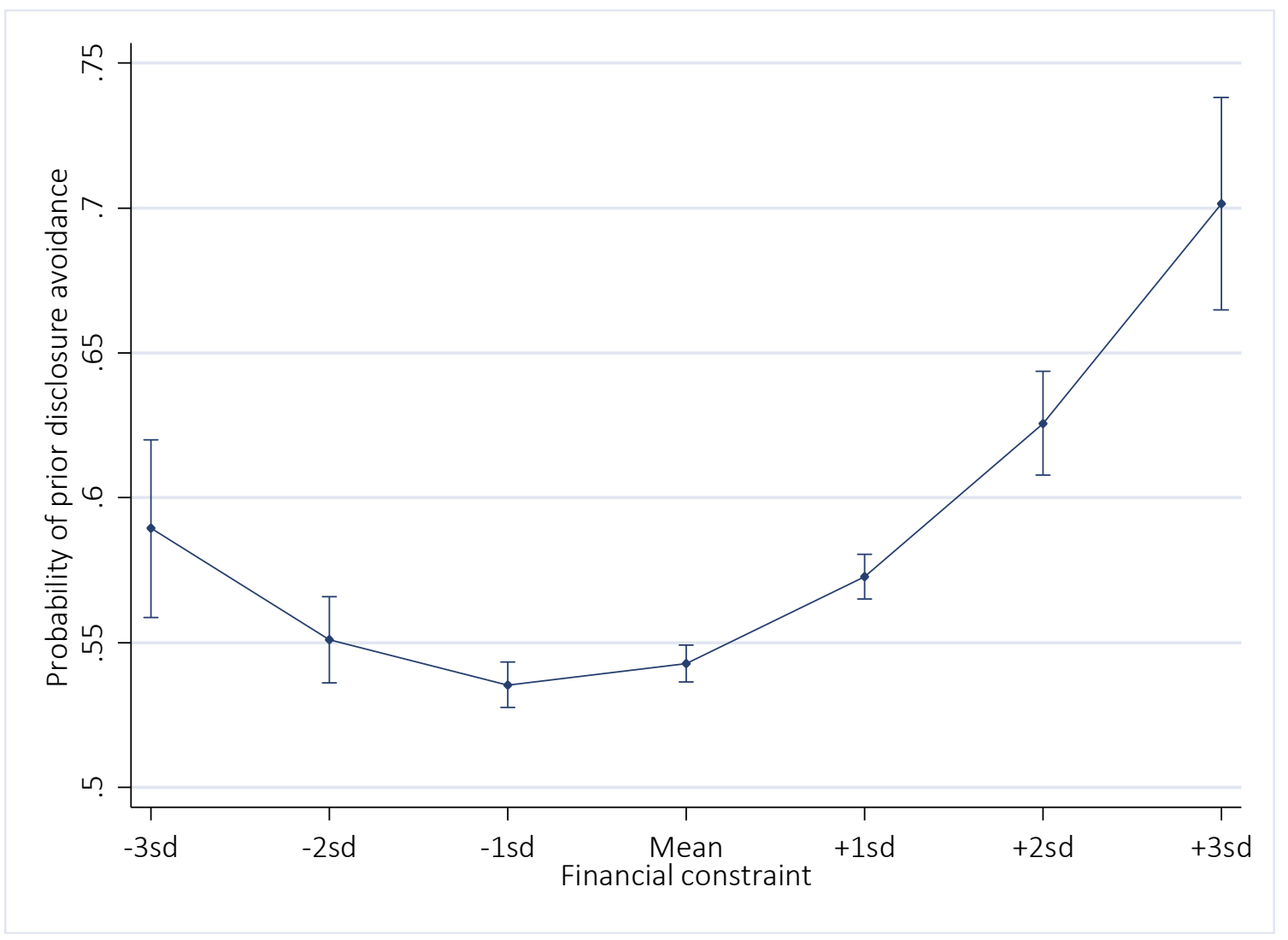




\section{Figure 3}

Disclosure avoidance and other costs and benefits of disclosure

This figure plots estimated margins and corresponding $95 \%$ confidence intervals of prior disclosure avoidance (no disclosure) for [-3 standard deviations, +3 standard deviations] of relative operating profitability (industry adjusted ROA), intangibility (intangibles), market concentration (Herfindahl-Hirschman index), and firm size (natural log of total assets). No disclosure is an indicator variable equal to one if the firm's first financial statement filing included in the Amadeus database is for its fiscal year end on or after December 31, 2005, and zero if before. Industry adjusted ROA equals the firm's operating profits, scaled by total assets, minus the mean of this ratio for all other private limited liability firms in the same 4-digit NAICS code. Intangibles equals the firm's intangible assets, scaled by total assets. The Herfindahl-Hirschman index is formed by 4-digit NAICS code and constructed using total assets of German firms with publicly disclosed financial statement information. All continuous variables are winsorized at the $1^{\text {st }}$ and $99^{\text {th }}$ percentiles and standardized to have a mean equal to zero and a standard deviation equal to one. Estimated margins are computed based on Equation (1), as estimated in Table 3, column 6.
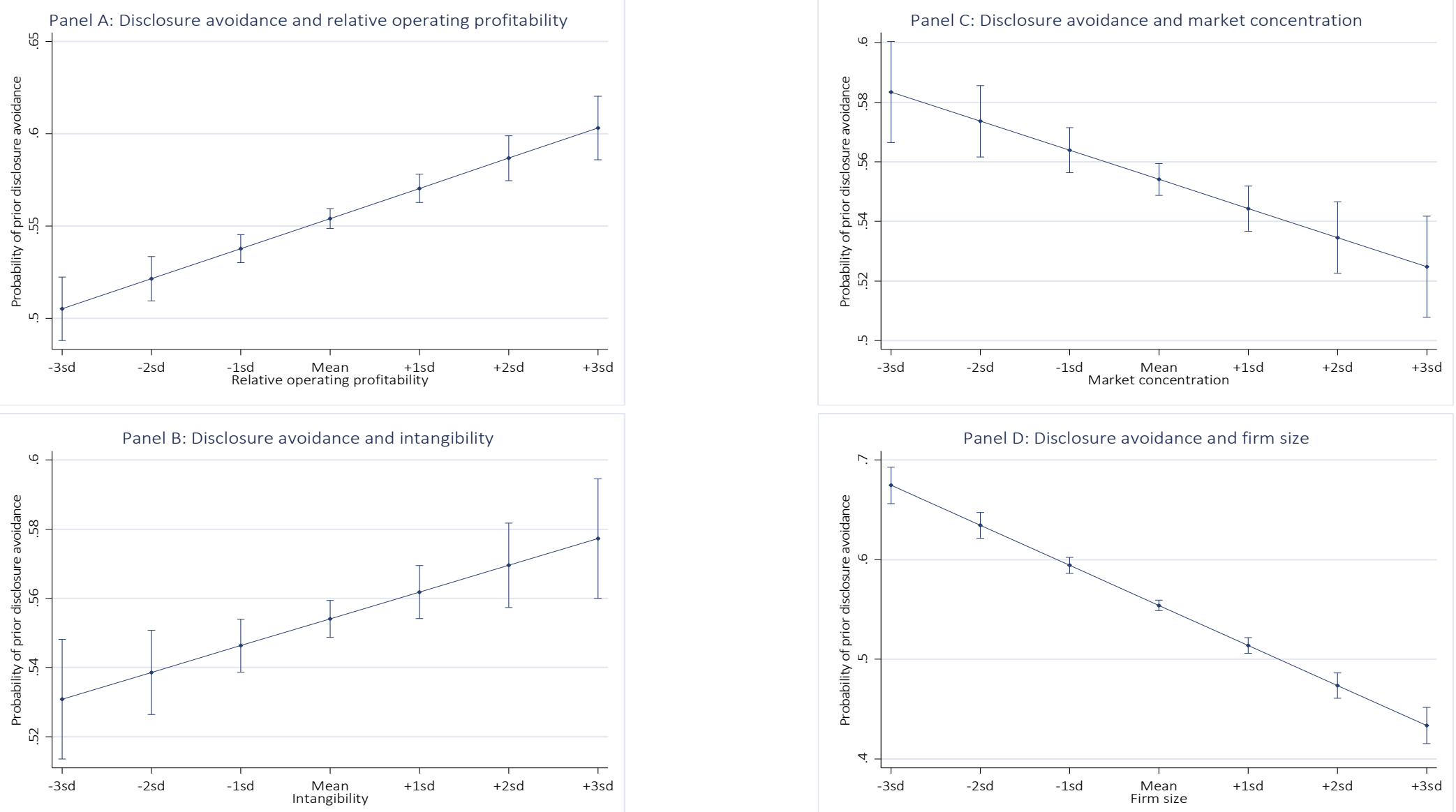


\section{Figure 4}

Disclosure avoidance and interactive effects with financial constraint

This figure plots estimated margins and corresponding $95 \%$ confidence intervals of prior disclosure avoidance (no disclosure) for [ -3 standard deviations, +3 standard deviations] of financial constraint (industry adjusted leverage net of cash) at representative values of relative size ( $10^{\text {th }}$ and $90^{\text {th }}$ percentiles of industry adjusted natural log of total assets), relative operating profitability ( $10^{\text {th }}$ and $90^{\text {th }}$ percentiles of industry adjusted ROA), public firm presence (public rival equals zero or one), and the propensity for ex ante sales contracting (ex ante contracting equals zero or one). No disclosure is an indicator variable equal to one if the firm's first financial statement filing included in the Amadeus database is for its fiscal year end on or after December 31, 2005, and zero if before. Industry adjusted leverage net of cash equals the firm's total debt net of cash, scaled by total assets, minus the mean of this ratio for all other private limited liability firms in the same 4-digit NAICS code. Industry adjusted natural log of total assets equals the natural logarithm of the firm's total assets, minus the mean of the natural logarithm of private limited liability firms' total assets in the same 4-digit NAICS code. Industry adjusted ROA equals the firm's operating profits, scaled by total assets, minus the mean of this ratio for all other private limited liability firms in the same 4-digit NAICS code. Public rival is an indicator variable equal to one if the firm's 4-digit NAICS code includes at least one public German firm, and zero otherwise. Ex ante contracting is an indicator variable equal to one if the firm is in a manufacturing industry (NAICS codes 31-33) that produces "differentiated products" based on the product homogeneity classification scheme in Rauch (1999), and zero otherwise. All continuous variables are winsorized at the $1^{\text {st }}$ and $99^{\text {th }}$ percentiles and standardized to have a mean equal to zero and a standard deviation equal to one. Estimated margins are computed based on Equation (2), as estimated in Table 4, columns 1 - 4 .
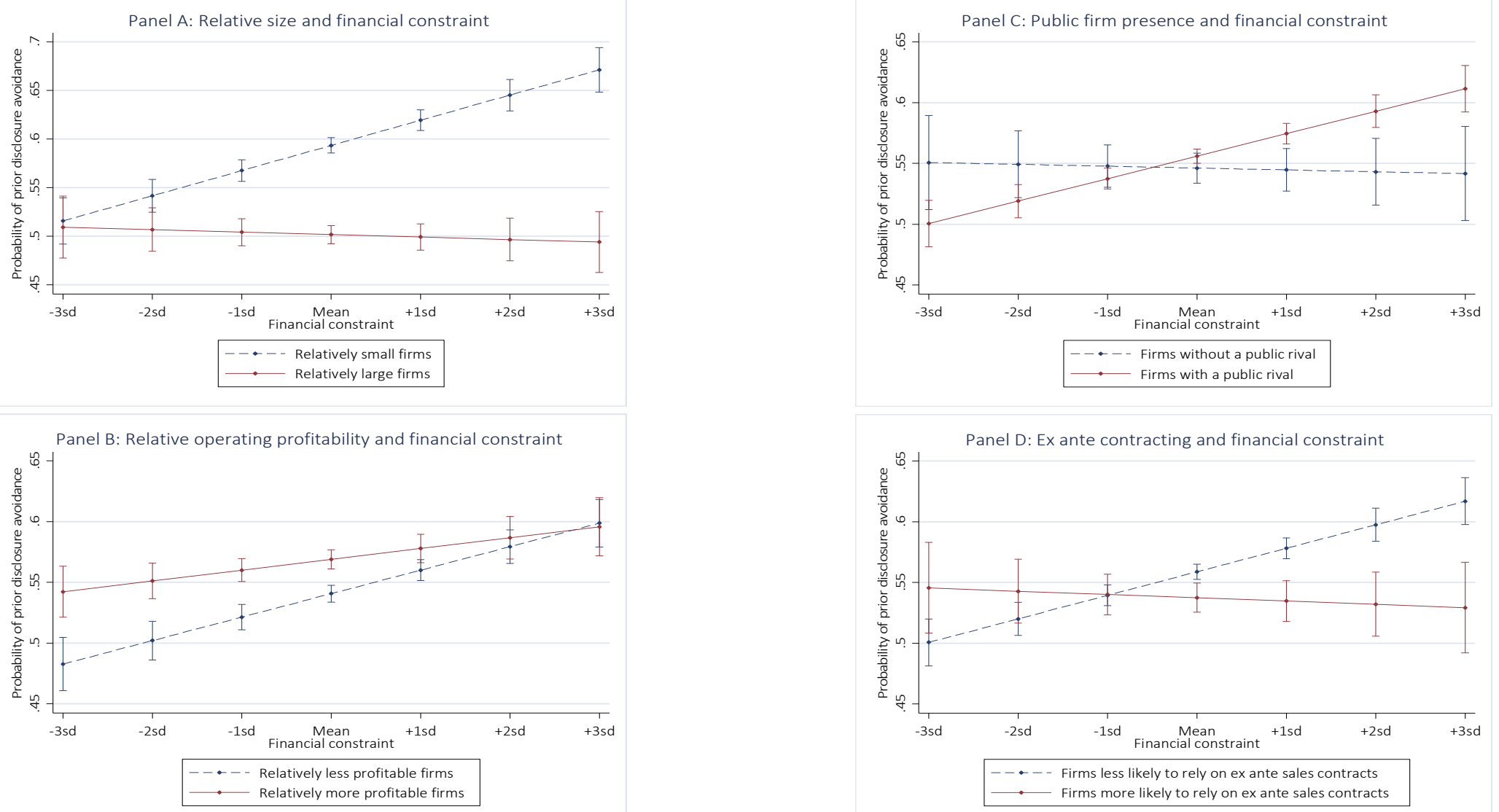


\section{Table 1}

Sample selection

This table presents the sample selection procedure. Data are obtained from the January 2012 version of the Bureau van Dijk database Amadeus.

German firm observations with fiscal year ends December 31, 2006 - December 30, 2007:

Less observations of firms:

without limited liability

without region, industry, or incorporation data

with total assets less than or equal to 4,015,000 euro

$(767,834)$

missing balance sheet or operating profit data

incorporated in 2005 or later

Final sample

31,035 
Table 2

Descriptive statistics

This table presents descriptive statistics on the sample. Panel A presents the mean level of prior disclosure avoidance (no disclosure) and the number of observations $(\mathrm{N})$ in the final sample by industry (two-digit NAICS code). Panel B presents summary statistics on the independent variables included in Equations (1) and (2), including the continuous variables before they are standardized to have a mean equal to zero and a standard deviation equal to one. Panel $\mathrm{C}$ presents summary statistics on the continuous variables after standardization. Panel D presents Pearson correlations. No disclosure is an indicator variable equal to one if the firm's first financial statement filing included in the Amadeus database is for its fiscal year end on or after December 31,2005 , and zero if before. Industry adjusted leverage net of cash equals the firm's total debt net of cash, scaled by total assets, minus the mean of this ratio for all other private limited liability firms in the same 4-digit NAICS code. Industry adjusted ROA equals the firm's operating profits, scaled by total assets, minus the mean of this ratio for all other private limited liability firms in the same 4-digit NAICS code. Intangibles equals the firm's intangible assets, scaled by total assets. The Herfindahl-Hirschman index is formed by 4-digit NAICS code and constructed using total assets of German firms with publicly disclosed financial statement information. Public rival is an indicator variable equal to one if the firm's 4-digit NAICS code includes at least one public German firm, and zero otherwise. High labor enforcement is an indicator variable equal to one if the firm operates in an industry subject to additional scrutiny under German labor laws (i.e., industries in the 3-digit NAICS codes 113, 236, 237, 238, 481, 482, 483, 484, 485, 486, 487, 488, 721, and 722, as well as the 4-digit NAICS codes 3116, 5612, and 5617), and zero otherwise. Sales missing is an indicator variable equal to one if the firm does not report sales, and zero otherwise. East German is an indicator variable equal to one if the firm is located in East Germany, and zero otherwise. Income per capita equals the average disposable income of residents in the district where the firm is located (in thousands). Industry adjusted natural log of total assets equals the natural logarithm of the firm's total assets, minus the mean of the natural logarithm of private limited liability firms' total assets in the same 4-digit NAICS code. Ex ante contracting is an indicator variable equal to one if the firm is in a manufacturing industry (NAICS codes 31-33) that produces "differentiated products" based on the product homogeneity classification scheme in Rauch (1999), and zero otherwise. All continuous variables are winsorized at the $1^{\text {st }}$ and $99^{\text {th }}$ percentiles and standardized to have a mean equal to zero and a standard deviation equal to one.

Panel A: Mean of prior disclosure avoidance and observation count by industry

$\begin{array}{cc}\text { Mean } & \mathrm{N} \\ 0.56 & 59 \\ 0.57 & 46 \\ 0.28 & 892 \\ 0.48 & 1,586 \\ 0.56 & 1,131 \\ 0.54 & 2,440 \\ 0.54 & 5,397 \\ 0.61 & 6,113 \\ 0.62 & 995 \\ 0.61 & 241 \\ 0.56 & 1,243 \\ 0.39 & 64 \\ 0.55 & 469 \\ 0.55 & 249 \\ 0.50 & 2,092 \\ 0.57 & 2,017 \\ 0.61 & 2,144 \\ 0.54 & 1,159 \\ 0.53 & 161 \\ 0.56 & 1,508 \\ 0.45 & 246 \\ 0.54 & 173 \\ 0.58 & 508 \\ 0.37 & 102 \\ 0.55 & 31,035 \\ & \\ 0.59\end{array}$

Agriculture, forestry, fishing and hunting

Mining, quarrying, and oil and gas extraction 9

Utilities

Construction

Food and textile manufacturing

, 440

Wood product, chemical, and nonmetallic mineral manufacturing

5,397

Metal, machinery, electronics, transportation, and furniture manufacturing

6,113

Motor vehicle, furniture, electronics, materials, food, health, and clothing retail

Sporting goods, general merchandise, miscellaneous, and non-store retail

Transportation

Information

Finance and insurance

Real estate and rental and leasing

Management of companies and enterprises

Administrative and support and waste management and remediation services

Educational services

Health care and social assistance

Arts, entertainment, and recreation

Accommodation and food services 
Panel B: Unstandardized variables

Industry adjusted leverage net of cash

Industry adjusted ROA

Intangibles

Herfindahl-Hirschman index

Natural log of total assets

Income per capita

Year incorporated

Industry adjusted natural log of total assets

Public rival

High labor enforcement

Sales missing

East German

Ex ante contracting

Panel C: Standardized continuous variables

Industry adjusted leverage net of cash

Industry adjusted ROA

Intangibles

Herfindahl-Hirschman index

Natural log of total assets

Income per capita

Year incorporated

Industry adjusted natural log of total assets

$\begin{array}{cccccc}10 \% & 25 \% & \text { Median } & 75 \% & 90 \% & \text { Mean } \\ -0.43 & -0.19 & 0.03 & 0.20 & 0.32 & -0.01 \\ -0.12 & -0.07 & -0.02 & 0.05 & 0.14 & -0.01 \\ 0.00 & 0.00 & 0.00 & 0.01 & 0.03 & 0.02 \\ 0.01 & 0.01 & 0.03 & 0.07 & 0.21 & 0.07 \\ 15.41 & 15.71 & 16.30 & 17.24 & 18.34 & 16.63 \\ 15.23 & 16.27 & 17.98 & 19.42 & 20.84 & 18.05 \\ 1967 & 1979 & 1990 & 1998 & 2002 & 1986 \\ -1.12 & -0.76 & -0.23 & 0.53 & 1.45 & -0.01 \\ 0 & 1 & 1 & 1 & 1 & 0.81 \\ 0 & 0 & 0 & 0 & 1 & 0.10 \\ 0 & 0 & 0 & 1 & 1 & 0.35 \\ 0 & 0 & 0 & 0 & 1 & 0.13 \\ 0 & 0 & 0 & 0 & 1 & 0.22 \\ & & & & & \\ 10 \% & 25 \% & \text { Median } & 75 \% & 90 \% & \text { Mean } \\ -1.38 & -0.61 & 0.13 & 0.68 & 1.10 & 0 \\ -0.79 & -0.40 & -0.05 & 0.39 & 1.04 & 0 \\ -0.33 & -0.33 & -0.30 & -0.17 & 0.33 & 0 \\ -0.58 & -0.56 & -0.43 & 0.01 & 1.26 & 0 \\ -1.03 & -0.77 & -0.28 & 0.52 & 1.44 & 0 \\ -1.16 & -0.73 & -0.03 & 0.57 & 1.15 & 0 \\ -1.16 & -0.43 & 0.25 & 0.74 & 0.98 & 0 \\ -1.03 & -0.69 & -0.20 & 0.51 & 1.37 & 0\end{array}$


Panel D: Pearson correlation table

$$
\text { No disclosure }
$$

Industry adjusted leverage net of cash

Industry adjusted ROA

Intangibles

Herfindahl-Hirschman index

Public rival

Natural log of total assets

High labor enforcement

Sales missing

East German

Income per capita

Year incorporated

Industry adjusted natural log of total assets

Ex ante contracting
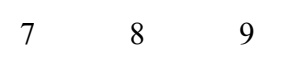

1

1

$0.02-$

$0.05-0.21$

$\begin{array}{llll}0.00 & 0.05 & -0.04 \quad-\end{array}$

$\begin{array}{llll}-0.02 & 0.00 & 0.02 & 0.02\end{array}$

$\left.\begin{array}{llllll}0.00 & 0.00 & -0.04 & 0.02 & -0.04\end{array}\right]$

$\begin{array}{llllll}-0.15 & -0.01 & -0.11 & 0.12 & 0.02 & 0.09\end{array}$

$\begin{array}{lllllll}-0.02 & 0.00 & 0.03 & -0.06 & -0.11 & -0.16 & -0.09\end{array}$

$\begin{array}{lllllllll}0.22 & -0.08 & 0.09 & -0.09 & -0.02 & -0.04 & -0.35 & 0.00 & -\end{array}$

$\begin{array}{lllllllll}-0.11 & -0.05 & -0.04 & -0.05 & 0.02 & -0.03 & -0.03 & 0.03 & -0.06\end{array}$

$\begin{array}{llllllllll}0.04 & 0.01 & 0.03 & 0.05 & -0.01 & 0.06 & 0.06 & -0.04 & 0.01 & -0.49\end{array}$

$\begin{array}{cccccccccc}0.06 & 0.04 & -0.01 & 0.07 & -0.01 & 0.02 & -0.09 & -0.03 & 0.00 & 0.17 \\ -0.14 & 0.00 & -0.08 & 0.10 & 0.00 & 0.00 & 0.91 & 0.00 & -0.30 & -0.03\end{array}$

$\begin{array}{llllllllll}-0.14 & 0.00 & -0.08 & 0.10 & 0.00 & 0.00 & 0.91 & 0.00 & -0.30 & -0.03\end{array}$

$\begin{array}{lllll}0.00 & 0.00 & 0.04 & 0.00 & 0.23\end{array}$

$0.01 \quad-0.06 \quad-0.18$

$0.08 \quad 0.01$

$-0.07 \quad-$

$0.04 \quad-0.13 \quad-$

Ex ante contracting 
Table 3

Determinants of disclosure avoidance

This table presents the results of estimating Equation (1) using ordinary least squares. No disclosure, the dependent variable, is an indicator variable equal to one if the firm's first financial statement filing included in the Amadeus database is for its fiscal year end on or after December 31, 2005, and zero if before. Industry adjusted leverage net of cash equals the firm's total debt net of cash, scaled by total assets, minus the mean of this ratio for all other private limited liability firms in the same 4-digit NAICS code. Industry adjusted ROA equals the firm's operating profits, scaled by total assets, minus the mean of this ratio for all other private limited liability firms in the same 4-digit NAICS code. Intangibles equals the firm's intangible assets, scaled by total assets. The Herfindahl-Hirschman index is formed by 4-digit NAICS code and constructed using total assets of German firms with publicly disclosed financial statement information. Public rival is an indicator variable equal to one if the firm's 4-digit NAICS code includes at least one public German firm, and zero otherwise. High labor enforcement is an indicator variable equal to one if the firm operates in an industry subject to additional scrutiny under German labor laws (i.e., industries in the 3-digit NAICS codes 113, 236, 237, 238, 481, 482, 483, 484, 485, 486, 487, 488, 721, and 722, as well as the 4-digit NAICS codes 3116,5612 , and 5617), and zero otherwise. Sales missing is an indicator variable equal to one if the firm does not report sales, and zero otherwise. East German is an indicator variable equal to one if the firm is located in East Germany, and zero otherwise. Income per capita equals the average disposable income of residents in the district where the firm is located (in thousands). All continuous variables are winsorized at the $1^{\text {st }}$ and $99^{\text {th }}$ percentiles and standardized to have a mean equal to zero and a standard deviation equal to one. T-statistics (in parentheses) are calculated using heteroskedastic-consistent Huber-White standard errors. Statistical significance at the $1 \%, 5 \%$, and $10 \%$ (two-tailed) levels are denoted with $* * *, * *$, and $*$, respectively.

\begin{tabular}{|c|c|c|c|c|c|c|c|}
\hline Model & Predict & 1 & 2 & 3 & 4 & 5 & 6 \\
\hline Industry adjusted leverage net of cash & $(+)$ & $\begin{array}{c}0.009 * * * \\
(3.26)\end{array}$ & $\begin{array}{c}0.012 * * * \\
(4.31)\end{array}$ & $\begin{array}{c}0.015 * * * \\
(5.26)\end{array}$ & $\begin{array}{c}0.015^{* * *} \\
\quad(5.21)\end{array}$ & $\begin{array}{c}0.015^{* * *} \\
(5.53)\end{array}$ & $\begin{array}{c}0.019 * * * \\
(6.53)\end{array}$ \\
\hline Industry adjusted leverage net of cash ${ }^{2}$ & $(+)$ & & & & $\begin{array}{c}0.018 * * * \\
(9.50)\end{array}$ & $\begin{array}{c}0.011 * * * \\
(6.00)\end{array}$ & $\begin{array}{c}0.011 * * * \\
(6.21)\end{array}$ \\
\hline Industry adjusted ROA & $(+)$ & & & $\begin{array}{c}0.016^{* * *} \\
(5.59)\end{array}$ & & & $\begin{array}{c}0.016^{* * *} \\
(5.88)\end{array}$ \\
\hline Intangibles & $(+)$ & & & $\begin{array}{c}0.008 * * * \\
(2.80)\end{array}$ & & & $\begin{array}{c}0.008 * * * \\
(2.76)\end{array}$ \\
\hline Herfindahl-Hirschman index & $(?)$ & & & $\begin{array}{c}-0.010 * * * \\
(-3.58)\end{array}$ & & & $\begin{array}{c}-0.010 * * * \\
(-3.56)\end{array}$ \\
\hline Public rival & $(+)$ & & & $\begin{array}{l}0.010 \\
(1.39)\end{array}$ & & & $\begin{array}{l}0.010 \\
(1.38)\end{array}$ \\
\hline Natural log of total assets & $(-)$ & & $\begin{array}{c}-0.042 * * * \\
(-14.15)\end{array}$ & $\begin{array}{c}-0.041 * * * \\
(-13.88)\end{array}$ & & $\begin{array}{c}-0.041 * * * \\
(-13.85)\end{array}$ & $\begin{array}{c}-0.040 * * * \\
(-13.54)\end{array}$ \\
\hline High labor enforcement & $(-)$ & & $\begin{array}{c}-0.043 * * * \\
(-4.83)\end{array}$ & $\begin{array}{c}-0.045 * * * \\
(-4.91)\end{array}$ & & $\begin{array}{c}-0.043 * * * \\
(-4.76)\end{array}$ & $\begin{array}{c}-0.044 * * * \\
(-4.83)\end{array}$ \\
\hline Sales missing & $(+)$ & & $\begin{array}{c}0.190 * * * \\
(31.29)\end{array}$ & $\begin{array}{c}0.190 * * * \\
(31.11)\end{array}$ & & $\begin{array}{c}0.189 * * * \\
(31.18)\end{array}$ & $\begin{array}{c}0.189 * * * \\
(30.98)\end{array}$ \\
\hline East German & $(?)$ & & $\begin{array}{c}-0.161 * * * \\
(-16.86)\end{array}$ & $\begin{array}{c}-0.157 * * * \\
(-16.40)\end{array}$ & & $\begin{array}{c}-0.160 * * * \\
(-16.76)\end{array}$ & $\begin{array}{c}-0.156^{* * *} \\
(-16.28)\end{array}$ \\
\hline Income per capita & $(?)$ & & $\begin{array}{l}-0.003 \\
(-0.85)\end{array}$ & $\begin{array}{l}-0.003 \\
(-1.02)\end{array}$ & & $\begin{array}{l}-0.004 \\
(-1.09)\end{array}$ & $\begin{array}{l}-0.004 \\
(-1.27)\end{array}$ \\
\hline Year incorporated & $(+)$ & & $\begin{array}{c}0.034 * * * \\
(12.29)\end{array}$ & $\begin{array}{c}0.033 * * * \\
(11.92)\end{array}$ & & $\begin{array}{c}0.033 * * * \\
(11.91)\end{array}$ & $\begin{array}{c}0.032 * * * \\
(11.53)\end{array}$ \\
\hline Constant & $(?)$ & $\begin{array}{c}0.554 * * * \\
(196.40) \\
\end{array}$ & $\begin{array}{c}0.514 * * * \\
(129.48) \\
\end{array}$ & $\begin{array}{c}0.505 * * * \\
(71.00) \\
\end{array}$ & $\begin{array}{c}0.536 * * * \\
(157.74) \\
\end{array}$ & $\begin{array}{c}0.503 * * * \\
(115.00) \\
\end{array}$ & $\begin{array}{c}0.494 * * * \\
(67.23) \\
\end{array}$ \\
\hline $\mathrm{R}^{2}$ & & 0.000 & 0.068 & 0.070 & 0.003 & 0.069 & 0.071 \\
\hline $\mathrm{N}$ & & 31,035 & 31,035 & 31,035 & 31,035 & 31,035 & 31,035 \\
\hline
\end{tabular}




\section{Table 4}

Cross-sectional tests of disclosure avoidance

This table presents the results of estimating Equation (2) using ordinary least squares. In columns 1 and 5 , natural $\log$ of total assets is replaced with industry adjusted natural log of total assets to ensure any main effect of industry adjusted natural $\log$ of total assets does not bias the interaction term. For similar reasons, the main effect of ex ante contracting is included in columns 4 and 5. No disclosure, the dependent variable, is an indicator variable equal to one if the firm's first financial statement filing included in the Amadeus database is for its fiscal year end on or after December 31,2005, and zero if before. Industry adjusted leverage net of cash equals the firm's total debt net of cash, scaled by total assets, minus the mean of this ratio for all other private limited liability firms in the same 4-digit NAICS code. Industry adjusted natural log of total assets equals the natural logarithm of the firm's total assets, minus the mean of the natural logarithm of private limited liability firms' total assets in the same 4-digit NAICS code. Industry adjusted ROA equals the firm's operating profits, scaled by total assets, minus the mean of this ratio for all other private limited liability firms in the same 4-digit NAICS code. Public rival is an indicator variable equal to one if the firm's 4-digit NAICS code includes at least one public German firm, and zero otherwise. Ex ante contracting is an indicator variable equal to one if the firm is in a manufacturing industry (NAICS codes 31-33) that produces "differentiated products" based on the product homogeneity classification scheme in Rauch (1999), and zero otherwise. Intangibles equals the firm's intangible assets, scaled by total assets. The Herfindahl-Hirschman index is formed by 4-digit NAICS code and constructed using total assets of German firms with publicly disclosed financial statement information. High labor enforcement is an indicator variable equal to one if the firm operates in an industry subject to additional scrutiny under German labor laws (i.e., industries in the 3-digit NAICS codes 113, 236, 237, 238, 481, 482, 483, 484, 485, 486, 487, 488, 721, and 722, as well as the 4-digit NAICS codes 3116, 5612, and 5617), and zero otherwise. Sales missing is an indicator variable equal to one if the firm does not report sales, and zero otherwise. East German is an indicator variable equal to one if the firm is located in East Germany, and zero otherwise. Income per capita equals the average disposable income of residents in the district where the firm is located (in thousands). All continuous variables are winsorized at the $1^{\text {st }}$ and $99^{\text {th }}$ percentiles and standardized to have a mean equal to zero and a standard deviation equal to one. Tstatistics (in parentheses) are calculated using heteroskedastic-consistent Huber-White standard errors. Statistical significance at the $1 \%, 5 \%$, and $10 \%$ (two-tailed) levels are denoted with $* * *, * *$, and *, respectively.

\begin{tabular}{|c|c|c|c|c|c|c|}
\hline Model & Predict & 1 & 2 & 3 & 4 & 5 \\
\hline Industry adjusted leverage net of cash & & $\begin{array}{c}0.014 * * * \\
(4.83)\end{array}$ & $\begin{array}{l}0.015^{* * *} \\
(5.29)\end{array}$ & $\begin{array}{l}-0.002 \\
(-0.24)\end{array}$ & $\begin{array}{l}0.019 * * * \\
(6.21)\end{array}$ & $\begin{array}{l}0.003 \\
(0.45)\end{array}$ \\
\hline $\begin{array}{l}\text { Industry adjusted leverage net of cash } \times \\
\text { Industry adjusted natural log of total assets }\end{array}$ & $(-)$ & $\begin{array}{c}-0.012 * * * \\
(-4.22)\end{array}$ & & & & $\begin{array}{c}-0.012 * * * \\
(-4.23)\end{array}$ \\
\hline $\begin{array}{l}\text { Industry adjusted leverage net of cash } \times \\
\text { Industry adjusted ROA }\end{array}$ & $(-)$ & & $\begin{array}{c}-0.006^{* *} \\
(-2.54)\end{array}$ & & & $\begin{array}{c}-0.007 * * * \\
(-2.93)\end{array}$ \\
\hline $\begin{array}{l}\text { Industry adjusted leverage net of cash } \times \text { Public } \\
\text { rival }\end{array}$ & $(+)$ & & & $\begin{array}{l}0.020^{* * *} \\
(2.90)\end{array}$ & & $\begin{array}{l}0.019 * * * \\
(2.72)\end{array}$ \\
\hline $\begin{array}{l}\text { Industry adjusted leverage net of cash } \times \text { Ex ante } \\
\text { contracting }\end{array}$ & $(-)$ & & & & $\begin{array}{c}-0.022 * * * \\
(-3.30)\end{array}$ & $\begin{array}{c}-0.021 * * * \\
(-3.16)\end{array}$ \\
\hline Industry adjusted ROA & $(+)$ & $\begin{array}{c}0.017 * * * \\
(6.13)\end{array}$ & $\begin{array}{l}0.015^{* * *} \\
(5.52)\end{array}$ & $\begin{array}{l}0.016^{* * *} \\
(5.60)\end{array}$ & $\begin{array}{l}0.015^{* * *} \\
(5.51)\end{array}$ & $\begin{array}{c}0.017 * * * \\
(5.95)\end{array}$ \\
\hline Intangibles & $(+)$ & $\begin{array}{l}0.007 * * * \\
(2.64)\end{array}$ & $\begin{array}{c}0.008 * * * \\
(2.80)\end{array}$ & $\begin{array}{c}0.008 * * * \\
(2.79)\end{array}$ & $\begin{array}{c}0.008 * * * \\
(2.82)\end{array}$ & $\begin{array}{c}0.007 * * * \\
(2.64)\end{array}$ \\
\hline Herfindahl-Hirschman index & (?) & $\begin{array}{c}-0.010^{* * *} \\
(-3.75)\end{array}$ & $\begin{array}{c}-0.010^{* * *} \\
(-3.62)\end{array}$ & $\begin{array}{c}-0.010^{* * *} \\
(-3.57)\end{array}$ & $\begin{array}{c}-0.008^{* * *} \\
(-2.82)\end{array}$ & $\begin{array}{c}-0.009 * * * \\
(-3.21)\end{array}$ \\
\hline Public rival & $(+)$ & $\begin{array}{l}0.002 \\
(0.27)\end{array}$ & $\begin{array}{l}0.010 \\
(1.38)\end{array}$ & $\begin{array}{l}0.010 \\
(1.39)\end{array}$ & $\begin{array}{l}0.010 \\
(1.43)\end{array}$ & $\begin{array}{l}0.002 \\
(0.26)\end{array}$ \\
\hline Industry adjusted natural log of total assets & $(-)$ & $\begin{array}{c}-0.038^{* * * *} \\
(-13.14)\end{array}$ & & & & $\begin{array}{r}-0.038^{* * *} \\
(-13.03)\end{array}$ \\
\hline Natural log of total assets & $(-)$ & & $\begin{array}{c}-0.041 * * * \\
(-13.72)\end{array}$ & $\begin{array}{c}-0.041 * * * \\
(-13.88)\end{array}$ & $\begin{array}{c}-0.042 * * * \\
(-14.08)\end{array}$ & \\
\hline High labor enforcement & $(-)$ & $\begin{array}{c}-0.035 * * * \\
(-3.87)\end{array}$ & $\begin{array}{c}-0.045^{* * * *} \\
(-4.90)\end{array}$ & $\begin{array}{c}-0.045^{* * *} \\
(-4.90)\end{array}$ & $\begin{array}{c}-0.050^{* * * *} \\
(-5.35)\end{array}$ & $\begin{array}{c}-0.039 * * * \\
(-4.18)\end{array}$ \\
\hline Sales missing & $(+)$ & $\begin{array}{c}0.195 * * * \\
(32.56)\end{array}$ & $\begin{array}{c}0.189 * * * \\
(31.09)\end{array}$ & $\begin{array}{c}0.190 * * * \\
(31.12)\end{array}$ & $\begin{array}{c}0.191 * * * \\
(31.23)\end{array}$ & $\begin{array}{c}0.196 * * * \\
(32.56)\end{array}$ \\
\hline East German & (?) & $\begin{array}{c}-0.157 * * * \\
(-16.47)\end{array}$ & $\begin{array}{c}-0.156^{* * * *} \\
(-16.33)\end{array}$ & $\begin{array}{c}-0.157 * * * \\
(-16.43)\end{array}$ & $\begin{array}{c}-0.156^{* * *} \\
(-16.37)\end{array}$ & $\begin{array}{c}-0.157 * * * \\
(-16.38)\end{array}$ \\
\hline Income per capita & (?) & $\begin{array}{l}-0.004 \\
(-1.11)\end{array}$ & $\begin{array}{l}-0.003 \\
(-1.03)\end{array}$ & $\begin{array}{l}-0.003 \\
(-1.02)\end{array}$ & $\begin{array}{l}-0.004 \\
(-1.12)\end{array}$ & $\begin{array}{l}-0.004 \\
(-1.21)\end{array}$ \\
\hline Year incorporated & $(+)$ & $\begin{array}{c}0.032 * * * \\
(11.57)\end{array}$ & $\begin{array}{c}0.033^{* * *} \\
(11.84)\end{array}$ & $\begin{array}{c}0.033 * * * \\
(11.96)\end{array}$ & $\begin{array}{c}0.032 * * * \\
(11.58)\end{array}$ & $\begin{array}{c}0.032^{* * * *} \\
(11.28)\end{array}$ \\
\hline Ex ante contracting & $(-)$ & & & & $\begin{array}{c}-0.021 * * * \\
(-3.07)\end{array}$ & $\begin{array}{c}-0.015^{* *} \\
(-2.22)\end{array}$ \\
\hline Constant & (?) & $\begin{array}{c}0.509^{* * *} \\
(71.19)\end{array}$ & $\begin{array}{c}0.504 * * * \\
(70.69)\end{array}$ & $\begin{array}{c}0.505^{* * *} \\
(71.04) \\
\end{array}$ & $\begin{array}{c}0.510 * * * \\
(70.25)\end{array}$ & $\begin{array}{c}0.511 * * * \\
(70.06)\end{array}$ \\
\hline $\mathrm{R}^{2}$ & & 0.070 & 0.070 & 0.070 & 0.070 & 0.071 \\
\hline $\mathrm{N}$ & & 31,035 & 31,035 & 31,035 & 31,035 & 31,035 \\
\hline
\end{tabular}


Table 5

First disclosure and the determinants of disclosure avoidance

This table presents the results of estimating Equation (1) using ordinary least squares, where column 1 excludes firms that first file December 31, 2006 - December 30, 2007 and column 2 excludes firms that first file December 31, 2005 - December 30 , 2006. No disclosure, the dependent variable, is an indicator variable equal to one if the firm's first financial statement filing included in the Amadeus database is for its fiscal year end on or after December 31, 2005, and zero if before. Industry adjusted leverage net of cash equals the firm's total debt net of cash, scaled by total assets, minus the mean of this ratio for all other private limited liability firms in the same 4-digit NAICS code. Industry adjusted ROA equals the firm's operating profits, scaled by total assets, minus the mean of this ratio for all other private limited liability firms in the same 4-digit NAICS code. Intangibles equals the firm's intangible assets, scaled by total assets. The Herfindahl-Hirschman index is formed by 4-digit NAICS code and constructed using total assets of German firms with publicly disclosed financial statement information. Public rival is an indicator variable equal to one if the firm's 4-digit NAICS code includes at least one public German firm, and zero otherwise. High labor enforcement is an indicator variable equal to one if the firm operates in an industry subject to additional scrutiny under German labor laws (i.e., industries in the 3-digit NAICS codes 113, 236, 237, 238, 481, 482, 483, 484, 485, 486, 487, 488, 721, and 722, as well as the 4-digit NAICS codes 3116, 5612, and 5617), and zero otherwise. Sales missing is an indicator variable equal to one if the firm does not report sales, and zero otherwise. East German is an indicator variable equal to one if the firm is located in East Germany, and zero otherwise. Income per capita equals the average disposable income of residents in the district where the firm is located (in thousands). All continuous variables are winsorized at the $1^{\text {st }}$ and $99^{\text {th }}$ percentiles and standardized to have a mean equal to zero and a standard deviation equal to one. T-statistics (in parentheses) are calculated using heteroskedastic-consistent Huber-White standard errors. Statistical significance at the 1\%, 5\%, and 10\% (twotailed) levels are denoted with $* * *, * *$, and $*$, respectively.

\begin{tabular}{|c|c|c|c|}
\hline Model & Predict & 1 & 2 \\
\hline Industry adjusted leverage net of cash & $(+)$ & $\begin{array}{c}0.017 * * * \\
(5.26)\end{array}$ & $\begin{array}{c}0.020 * * * \\
(5.69)\end{array}$ \\
\hline Industry adjusted leverage net of cash $^{2}$ & $(+)$ & $\begin{array}{c}0.008 * * * \\
(3.89)\end{array}$ & $\begin{array}{c}0.016^{* * *} \\
(6.90)\end{array}$ \\
\hline Industry adjusted ROA & $(+)$ & $\begin{array}{c}0.017 * * * \\
\quad(5.58)\end{array}$ & $\begin{array}{c}0.011 * * * \\
(3.68)\end{array}$ \\
\hline Intangibles & $(+)$ & $\begin{array}{c}0.005^{*} \\
(1.68)\end{array}$ & $\begin{array}{c}0.010^{* * *} \\
(2.82)\end{array}$ \\
\hline Herfindahl-Hirschman index & $(?)$ & $\begin{array}{c}-0.007 * * \\
(-2.42)\end{array}$ & $\begin{array}{c}-0.011 * * * \\
(-3.82)\end{array}$ \\
\hline Public rival & $(+)$ & $\begin{array}{l}0.007 \\
(0.88)\end{array}$ & $\begin{array}{c}0.015^{*} \\
(1.89)\end{array}$ \\
\hline Natural log of total assets & $(-)$ & $\begin{array}{c}-0.046 * * * \\
(-14.73)\end{array}$ & $\begin{array}{c}-0.015 * * * \\
(-4.97)\end{array}$ \\
\hline High labor enforcement & $(-)$ & $\begin{array}{c}-0.050 * * * \\
(-5.06)\end{array}$ & $\begin{array}{c}-0.022 * * \\
(-2.19)\end{array}$ \\
\hline Sales missing & $(+)$ & $\begin{array}{c}0.193 * * * \\
(27.97)\end{array}$ & $\begin{array}{c}0.177 * * * \\
(22.39)\end{array}$ \\
\hline East German & $(?)$ & $\begin{array}{c}-0.158 * * * \\
(-15.73)\end{array}$ & $\begin{array}{c}-0.105 * * * \\
(-10.77)\end{array}$ \\
\hline Income per capita & $(?)$ & $\begin{array}{c}-0.006^{*} \\
(-1.82)\end{array}$ & $\begin{array}{l}-0.003 \\
(-0.98)\end{array}$ \\
\hline Year incorporated & $(+)$ & $\begin{array}{c}0.027 * * * \\
(8.82)\end{array}$ & $\begin{array}{c}0.032 * * * \\
(10.44)\end{array}$ \\
\hline Constant & $(?)$ & $\begin{array}{c}0.417 * * * \\
(52.23)\end{array}$ & $\begin{array}{c}0.213^{* * *} \\
(25.95)\end{array}$ \\
\hline $\mathrm{R}^{2}$ & & 0.073 & 0.058 \\
\hline $\mathrm{N}$ & & 25,895 & 18,979 \\
\hline
\end{tabular}


Table 6

Dimensions of market structure and disclosure avoidance

This table presents the results of estimating Equation (2) using ordinary least squares. In columns 1 and 2, CS variable is replaced with measures of product substitutability and cost of entry, respectively. In column 3 , the interactions for substitutability and cost of entry with industry adjusted leverage net of cash are added to the estimation tabulated in Table 4, column 5 . No disclosure, the dependent variable, is an indicator variable equal to one if the firm's first financial statement filing included in the Amadeus database is for its fiscal year end on or after December 31, 2005, and zero if before. Industry adjusted leverage net of cash equals the firm's total debt net of cash, scaled by total assets, minus the mean of this ratio for all other private limited liability firms in the same 4-digit NAICS code. Substitutability equals the negative of weighted-average operating return-onassets of firms by 4-digit NAICS code, where weights are based on firm size (total assets). Cost of entry equals the weightedaverage capital intensity of firms by 4-digit NAICS code, calculated as the weighted-average ratio of fixed assets to total assets. Industry adjusted natural log of total assets equals the natural logarithm of the firm's total assets, minus the mean of the natural logarithm of private limited liability firms' total assets in the same 4-digit NAICS code. Industry adjusted ROA equals the firm's operating profits, scaled by total assets, minus the mean of this ratio for all other private limited liability firms in the same 4-digit NAICS code. Public rival is an indicator variable equal to one if the firm's 4-digit NAICS code includes at least one public German firm, and zero otherwise. Ex ante contracting is an indicator variable equal to one if the firm is in a manufacturing industry (NAICS codes 31-33) that produces "differentiated products" based on the product homogeneity classification scheme in Rauch (1999), and zero otherwise. All continuous variables are winsorized at the $1^{\text {st }}$ and $99^{\text {th }}$ percentiles and standardized to have a mean equal to zero and a standard deviation equal to one. For brevity, the coefficients and tests of statistical significance for control variables are suppressed in all columns. T-statistics (in parentheses) are calculated using heteroskedastic-consistent Huber-White standard errors. Statistical significance at the 1\%, 5\%, and 10\% (two-tailed) levels are denoted with ***, **, and *, respectively.

\begin{tabular}{|c|c|c|c|c|}
\hline Model & Predict & 1 & 2 & 3 \\
\hline Industry adjusted leverage net of cash & & $\begin{array}{c}0.014^{* * *} \\
\quad(4.98)\end{array}$ & $\begin{array}{c}0.014 * * * \\
(4.98)\end{array}$ & $\begin{array}{l}0.001 \\
(0.20)\end{array}$ \\
\hline Industry adjusted leverage net of cash $\times$ Substitutability & $(+)$ & $\begin{array}{l}0.010^{* * *} \\
(3.67)\end{array}$ & & $\begin{array}{c}0.007 * * \\
(2.10)\end{array}$ \\
\hline Industry adjusted leverage net of cash $\times$ Cost of entry & $(+)$ & & $\begin{array}{c}0.007 * * \\
(2.46)\end{array}$ & $\begin{array}{l}0.001 \\
(0.20)\end{array}$ \\
\hline $\begin{array}{l}\text { Industry adjusted leverage net of cash } \times \text { Industry adjusted natural } \\
\log \text { of total assets }\end{array}$ & $(-)$ & & & $\begin{array}{c}-0.012 * * * \\
(-4.13)\end{array}$ \\
\hline Industry adjusted leverage net of cash $\times$ Industry adjusted ROA & $(-)$ & & & $\begin{array}{c}-0.007 * * * \\
(-2.96)\end{array}$ \\
\hline Industry adjusted leverage net of cash $\times$ Public rival & $(+)$ & & & $\begin{array}{c}0.018 * * \\
(2.54)\end{array}$ \\
\hline Industry adjusted leverage net of cash $\times$ Ex ante contracting & $(-)$ & & & $\begin{array}{l}-0.013 * \\
(-1.67)\end{array}$ \\
\hline Constant & $(?)$ & $\begin{array}{c}0.508 * * * \\
(70.96)\end{array}$ & $\begin{array}{c}0.506^{* * *} \\
(70.96)\end{array}$ & $\begin{array}{c}0.512 * * * \\
(70.15)\end{array}$ \\
\hline $\mathrm{R}^{2}$ & & 0.070 & 0.070 & 0.071 \\
\hline $\mathrm{N}$ & & 31,035 & 31,035 & 31,035 \\
\hline
\end{tabular}


Table 7

Financial constraint, disclosure avoidance, and ex post performance

This table presents the results of several ex post tests of performance. Columns 1 and 2 examine the probability of survival; columns 3 and 4 examine the percentage change in cash holdings; columns 5 and 6 examine the percentage change in fixed assets; columns 7 and 8 examine the percentage change in industry market share (measured based on total assets and 4-digit NAICS codes). All changes are measured between the firm's filing between December 31, 2006 and December 30, 2007 and its filing two or three years later. Survival is an indicator variable equal to one if the firm remains on the Amadeus database, and zero otherwise. Values for $\% \Delta$ Cash, $\% \Delta$ Fixed assets, and $\% \Delta \mathrm{Market}$ share are replaced with their respective decile ranks to mitigate the effects of outliers. Industry adjusted leverage net of cash equals the firm's total debt net of cash, scaled by total assets, minus the mean of this ratio for all other private limited liability firms in the same 4-digit NAICS code. No disclosure is an indicator variable equal to one if the firm's first financial statement filing included in the Amadeus database is for its fiscal year end on or after December 31, 2005, and zero if before. Loss equals one for firms with negative operating profitability, and zero otherwise. Tangibility equals the ratio of fixed assets to total assets. Income per capita equals the average disposable income of residents in the district where the firm is located (in thousands). All continuous variables are winsorized at the $1^{\text {st }}$ and $99^{\text {th }}$ percentiles and standardized to have a mean equal to zero and a standard deviation equal to one. T-statistics (in parentheses) are calculated using heteroskedastic-consistent Huber-White standard errors. Statistical significance at the $1 \%, 5 \%$, and $10 \%$ (two-tailed) levels are denoted with ***,**, and *, respectively.

\begin{tabular}{|c|c|c|c|c|c|c|c|c|c|}
\hline $\begin{array}{l}\text { Model } \\
\text { Dependent variable }\end{array}$ & Predict & $\begin{array}{c}1 \\
\text { Survival } \\
2 \text { yrs } \\
\end{array}$ & $\begin{array}{c}2 \\
\text { Survival } \\
3 \text { yrs } \\
\end{array}$ & $\begin{array}{c}3 \\
\% \Delta \text { Cash } \\
2 \text { yrs } \\
\end{array}$ & $\begin{array}{c}4 \\
\% \Delta \text { Cash } \\
3 \mathrm{yrs} \\
\end{array}$ & $\begin{array}{c}5 \\
\% \Delta \text { Fixed assets } \\
2 \text { yrs } \\
\end{array}$ & $\begin{array}{c}6 \\
\% \Delta \text { Fixed assets } \\
3 \text { yrs } \\
\end{array}$ & $\begin{array}{c}7 \\
\% \Delta \text { Market share } \\
2 \text { yrs } \\
\end{array}$ & $\begin{array}{c}8 \\
\% \Delta \text { Market share } \\
3 \text { yrs } \\
\end{array}$ \\
\hline $\begin{array}{l}\text { Industry adjusted leverage } \\
\text { net of cash }\end{array}$ & $(-)$ & $\begin{array}{c}-0.013 * * * \\
(-5.92)\end{array}$ & $\begin{array}{c}-0.027 * * * \\
(-7.80)\end{array}$ & $\begin{array}{c}0.211 * * * \\
(8.22)\end{array}$ & $\begin{array}{c}0.239 * * * \\
(8.61)\end{array}$ & $\begin{array}{c}-0.148 * * * \\
(-5.52)\end{array}$ & $\begin{array}{c}-0.151 * * * \\
(-5.23)\end{array}$ & $\begin{array}{c}-0.085 * * * \\
(-3.34)\end{array}$ & $\begin{array}{c}-0.153 * * * \\
(-6.56)\end{array}$ \\
\hline $\begin{array}{l}\text { Industry adjusted leverage } \\
\text { net of cash } \times \text { No disclosure }\end{array}$ & $(-)$ & $\begin{array}{l}0.004 \\
(1.23)\end{array}$ & $\begin{array}{l}-0.000 \\
(-0.02)\end{array}$ & $\begin{array}{c}-0.071 * * \\
(-2.11)\end{array}$ & $\begin{array}{c}-0.109 * * * \\
(-2.99)\end{array}$ & $\begin{array}{l}-0.050 \\
(-1.42)\end{array}$ & $\begin{array}{c}-0.081 * * \\
(-2.13)\end{array}$ & $\begin{array}{l}-0.034 \\
(-1.00)\end{array}$ & $\begin{array}{c}-0.077 * * \\
(-2.46)\end{array}$ \\
\hline No disclosure & $(-)$ & $\begin{array}{c}-0.010 * * * \\
(-3.68)\end{array}$ & $\begin{array}{c}-0.030 * * * \\
(-6.71)\end{array}$ & $\begin{array}{l}-0.043 \\
(-1.23)\end{array}$ & $\begin{array}{l}-0.047 \\
(-1.25)\end{array}$ & $\begin{array}{c}-0.081 * * \\
(-2.38)\end{array}$ & $\begin{array}{c}-0.101 * * * \\
(-2.76)\end{array}$ & $\begin{array}{l}-0.045 \\
(-1.40)\end{array}$ & $\begin{array}{c}-0.065^{* *} \\
(-2.19)\end{array}$ \\
\hline Loss & $(-)$ & $\begin{array}{c}-0.030 * * * \\
(-6.88)\end{array}$ & $\begin{array}{c}-0.054 * * * \\
(-8.10)\end{array}$ & $\begin{array}{l}-0.045 \\
(-0.89)\end{array}$ & $\begin{array}{c}-0.248 * * * \\
(-4.45)\end{array}$ & $\begin{array}{c}-0.802 * * * \\
(-16.32)\end{array}$ & $\begin{array}{c}-0.724 * * * \\
(-13.40)\end{array}$ & $\begin{array}{c}-0.687 * * * \\
(-14.60)\end{array}$ & $\begin{array}{c}-0.579 * * * \\
(-13.26)\end{array}$ \\
\hline Natural log of total assets & $(+)$ & $\begin{array}{c}-0.016 * * * \\
(-9.77)\end{array}$ & $\begin{array}{c}-0.029 * * * \\
(-11.91)\end{array}$ & $\begin{array}{c}-0.076 * * * \\
(-4.21)\end{array}$ & $\begin{array}{c}-0.127 * * * \\
(-6.46)\end{array}$ & $\begin{array}{c}0.072 * * * \\
(4.21)\end{array}$ & $\begin{array}{c}0.074 * * * \\
(4.01)\end{array}$ & $\begin{array}{c}-0.141 * * * \\
(-8.47)\end{array}$ & $\begin{array}{c}-0.096 * * * \\
(-6.19)\end{array}$ \\
\hline Year incorporated & $(-)$ & $\begin{array}{c}-0.007 * * * \\
(-5.09)\end{array}$ & $\begin{array}{c}-0.023 * * * \\
(-10.77)\end{array}$ & $\begin{array}{c}-0.077 * * * \\
(-4.48)\end{array}$ & $\begin{array}{c}-0.076 * * * \\
(-4.15)\end{array}$ & $\begin{array}{c}-0.052 * * * \\
(-3.27)\end{array}$ & $\begin{array}{c}-0.044 * * \\
(-2.57)\end{array}$ & $\begin{array}{c}-0.048 * * * \\
(-3.12)\end{array}$ & $\begin{array}{c}-0.032 * * \\
(-2.28)\end{array}$ \\
\hline Tangibility & (?) & $\begin{array}{c}0.010^{* * *} \\
(6.71)\end{array}$ & $\begin{array}{c}0.024 * * * \\
(9.79)\end{array}$ & $\begin{array}{c}0.096 * * * \\
(5.22)\end{array}$ & $\begin{array}{c}0.066 * * * \\
(3.27)\end{array}$ & $\begin{array}{c}-0.500 * * * \\
(-29.11)\end{array}$ & $\begin{array}{c}-0.518 * * * \\
(-27.68)\end{array}$ & $\begin{array}{c}-0.112 * * * \\
(-6.41)\end{array}$ & $\begin{array}{c}-0.050^{* * *} \\
(-3.10)\end{array}$ \\
\hline Income per capita & (?) & $\begin{array}{l}-0.002 \\
(-1.47)\end{array}$ & $\begin{array}{c}-0.011 * * * \\
(-4.69)\end{array}$ & $\begin{array}{l}-0.030^{*} \\
(-1.75)\end{array}$ & $\begin{array}{l}-0.032 * \\
(-1.73)\end{array}$ & $\begin{array}{c}-0.080^{* * *} \\
(-4.66)\end{array}$ & $\begin{array}{c}-0.100^{* * *} \\
(-5.38)\end{array}$ & $\begin{array}{l}-0.030^{*} \\
(-1.81)\end{array}$ & $\begin{array}{l}0.000 \\
(0.03)\end{array}$ \\
\hline Constant & & $\begin{array}{c}0.948 * * * \\
(466.55) \\
\end{array}$ & $\begin{array}{c}0.833 * * * \\
(248.66) \\
\end{array}$ & $\begin{array}{l}5.522 * * * \\
(206.69) \\
\end{array}$ & $\begin{array}{c}5.561 * * * \\
(194.16) \\
\end{array}$ & $\begin{array}{l}5.670 * * * \\
(220.63) \\
\end{array}$ & $\begin{array}{l}5.666^{* * * *} \\
(205.45) \\
\end{array}$ & $\begin{array}{l}5.929 * * * \\
(242.64) \\
\end{array}$ & $\begin{array}{c}6.575 * * * \\
(294.14) \\
\end{array}$ \\
\hline $\begin{array}{l}\mathrm{R}^{2} \\
\mathrm{~N}\end{array}$ & & $\begin{array}{c}0.010 \\
31,035\end{array}$ & $\begin{array}{c}0.020 \\
31,035\end{array}$ & $\begin{array}{c}0.006 \\
28,024\end{array}$ & $\begin{array}{c}0.007 \\
24,270\end{array}$ & $\begin{array}{c}0.048 \\
28,281\end{array}$ & $\begin{array}{c}0.049 \\
24.510\end{array}$ & $\begin{array}{c}0.017 \\
28,620\end{array}$ & $\begin{array}{c}0.020 \\
24,780\end{array}$ \\
\hline
\end{tabular}

